\title{
Comment
}

\section{THE INDIAN BATTLE FOR SELF-DETERMINATION}

The present uncertain status of the Indian and his tribe in America is a product of more than a century of congressional vacillation between policies of separation and assimilation. As the Indians look increasingly to courts of law for the protection of their interests and the maintenance of tribal integrity, it is essential that a more stable set of principles be developed to govern the relationships between the Indians, the federal government, and the states. This Comment traces the history of congressional regulation of Indian affairs and analyzes the judicial response to the ever-changing congressional policies. That analysis provides both a basis for elaborating the sources of the principles that should form the field of Indian law and a framework within which to consider Indian cases.

The legal and political status of the Indian tribe, and the tribe's relationship to the states and to the United States Government, have remained an issue of controversy in American courtrooms and legislative halls ever since the newly independent colonies found it necessary to deal with the alien and often hostile native inhabitants of this continent. Federal courts have traditionally viewed the tribe as a dependent or "tributary" nation possessed of limited elements of sovereignty and requiring federal protection; ${ }^{1}$ the Congress has alternately viewed the tribe as a substantially imdependent political unit ${ }^{2}$ or as an anachronisin which inust be pliased out consequent to a policy of Indian assimilation. ${ }^{3}$ The states also have long been a party to the debate over the status of the Indian tribe, ${ }^{4}$ for Indian reservations exist within state boundaries and federal recognition of tribal sovereignty has often conflicted with the interests of state sovereignty. The individual Indian

1. See Worcester v. Georgia, 31 U.S. 350,6 Pet. 515 (1832); W. BRoPHY \& S. Aberle, The Indian, AMerica's UNFINISHEd Business 183 (1966) [hereinafter cited as BropHy \& ABERLE].

2. See F. Cohen, Handbook of Federal Indian LAW 122 (1945) [hereinafter cited as FEDERAL INDIAN LAw]. There are several editions of this treatise, but Cohen's scholarship remains unequaled and this edition has the advantage of complete tables of cases, statutes and departmental rulings. See discussion of congressional attitude toward tribal law in H.R. ReP. No. 474, 23d Cong., 1st Sess. 3 (1834).

3. See H.R. Con. Res. 108, Aug. 1, 1953, 67 Stat. B132. See also H.R. ReP. No. 848, 83d Cong., 1st Sess. 3 (1953).

4. See text discussing Worcester v. Georgia, infra at Part III (A). 
is, as of 1924, a citizen of the United States, ${ }^{5}$ but the status of his primary unit of social and political organization in the American federal system contimues to be a problem defying effective resolution by either the courts or the Congress.

The controversy over the status of the tribe mirrors the unsettled status of the individual Indian in the United States. Two conflicting policies-separation and assimilation-have been formulated to define the Indian's relationship to this society, but Congress, the ultimate arbiter of Indian affairs, has demonstrated a chronic inability finally to decide which of the two it will pursue. The former policy is designed to separate the Indian from the rest of American society and leave him a degree of self-government through his own imstitutions. The latter policy is calculated to place the Indian in the cultural "melting pot" and have him enter the inamstream of American society. The coexistence of these conflicting policies has created constant tension and uncertainty of direction in the body of law which governs the Indian and his tribe.

Congress has exercised its power over Indians for almost 200 years, and the plenary nature of that power has become an axiom of congressional Indian legislation. The federal judiciary, which has traditionally been more sensitive than Congress to the Indian's probleins and more sympathetic to the goals of separation, ${ }^{6}$ has attempted to mitigate the impact of fluctuating congressional policies. The courts liave recognized the plenary power of Congress to deal with Indian affairs and have never directly attacked it; but the propensity of the courts to isolate the sources of federal power in justifying congressional action mdicates their resistance to a congressional "carte blanche" in the field of Indian affairs.

This Comment will examine the historical roots of the body of federal law that relates to Indians, including the legislative policies toward Indians, their implementing programs, and the judicial response to those policies. Primary focus will be on the potential contributions of the courts in resolving the existing conflicts between the tribe, the states, and the federal government. Part I will examine the sources of federal plenary power over Indian affairs. Part III will trace the development of congressional legislation pertaming to Indians im the context of the competing policies of separation and assimilation. Part III will deal with the judicial attempt to define the roles of the federal govern-

5. Act of June 2, 1924, ch. 233, 43 Stat. 253. The codification of the extension of citizenship to Indians, 8 U.S.C. $\S 3$, was replaced by $\S 201$ (b) of the Nationality Act of October 14, 1940, ch. 876, 54 Stat. 1137, 1138.

6. See, e.g., Ex parte Crow Dog, 109 U.S. 556, 571 (1883). For a general discussion of the federal courts' treatment of tribal Indians see Cohen, Indian Rights and the Federal Courts, 24 MinN. L. REv. 145 (1940). 
ment, the states, and the tribe in response to changes in federal legislative policy. Part IV will analyze the recent attempts by the courts to provide direction in the area of Indian law in the face of congressional uncertainty.

\section{I}

THE SOURCES OF FEDERAL POWER

The plenary power of the United States Government over the Indian and his tribe emanates from three sources. First, the Constitution grants to the President ${ }^{7}$ and to Congress ${ }^{8}$ powers over Indian affairs which have been construed as giving broad authority to the federal government. ${ }^{2}$ Second, the courts have applied the theory of guardian and ward to the federal government's relationship to the tribe. ${ }^{10}$ Third, federal authority is inherent in the federal government's ownership of the land which the tribal units occupy. ${ }^{11}$

\section{A. The Constitutional Source-"The Power to Regulate Indians"}

The Constitution, as the supreme law of the United States, provides the legislative brancl, and, to a lesser degree, the executive branch of the federal government with a broad authorization for the exercise of power over Indian affairs. ${ }^{12}$ John Marshall recognized this fact in one of the first important Indian cases wlien he stated that the Constitution "confers on Congress the powers of war and peace; of making treaties, and of regulating commerce . . . with the Indian tribes. These powers comprehend all that is required for the regulation of our intercourse with the Indians. . . .13 Of the three constitutional elements of this general power to regulate Indians ${ }^{14}$, two-

7. U.S. CoNST. art. II, $\S 2$, cl. 2: "[The President] shall have Power, by and with the Advice and Consent of the Senate, to make Treaties ....."

8. Id. art. I, $\S 8$, cl. 3: "Congress shall have Power .... To regulate Commerce with foreign Nations, and among the several States, and with the Indian Tribes...."

9. Federax Indian LaW, supra note 2, at 89; United States v. Holliday, 70 U.S. (3 Wall.) 407, 417-18 (1866).

10. The theory of federal guardianship began with Cherokee Nation v. Georgia, 30 U.S. 1, 9, 5 Pet. 1, 12 (1831) (dicta). See the discussion of the theory in Part I(B) infra. For judicial application of the theory, see, e.g., United States v. Nice, 241 U.S. 591, 597-98 (1916); Tiger v. Western Investment Co., 221 U.S. 286, 315 (1911); United States v. Kagama, 118 U.S. 375, 383-84 (1886); United States v. Holliday, 70 U.S. ( 3 Wall.) 407, 418 (1866).

11. See Johnson \& Graham's Lessee v. McIntosh, 21 U.S. (8 Wheat.) 240, 259, 261 (1823); United States v. Kagama, 118 U.S. 375, 380 (1886).

12. See U.S. Const. art. II, $\S 2$, cl. 2 ; id. art. I, $\S 8$, cl. 3 , quoted in notes 7 \& 8 supra.

13. Worcester v. Georgia, 31 U.S. 350, 379, 6 Pet. 515, 559 (1832).

14. Federal Indian LaW, supta note 2 , at 89. 
the treatymaking and commerce powers-have had continuing importance to Indian law in their own right.

The treatymaking power authorizes the executive branch to negotiate treaties and the legislative branch to confirm them. ${ }^{15}$ The treaty was the accepted means for dealing with the Indian tribes until 1871 and was the only effective method for dealing with many tribes in the early days of the Republic when the Indian tribes were considered dependent nationalities and the Indian himself was viewed by the government as an ahen. ${ }^{18}$ The treaty was abandoned as a mode of Indian regulation in $1871,{ }^{17}$ but treaties sigued before that year continue in force until superseded by federal statute. ${ }^{18}$

As early as 1790, Congress began to exercise power over the Indian pursuant to the commerce clause of the Constitution. Starting in that year, Congress passed a series of "Indian Trade and Intercourse" acts ${ }^{19}$ which dealt with a variety of aspects of Indian affairs, from the scope of federal criminal jurisdiction over Indian land ${ }^{20}$ and the licensing of trade with Indian tribes ${ }^{21}$ to the annexation by territories of Indian land within territorial limits. ${ }^{22}$

One aspect of the Intercourse Acts, the federal prohibition of the sale of intoxicants to Indians, indicates the broad scope of Congress' commerce clause power to regulate Indian affairs. The prohibition, which forbade the sale of intoxicants to Indians and the introduction of same to Indian country, was first set out in the Intercourse Act of $1802,{ }^{23}$ and it remained an important element of federal Indian law until 1953. ${ }^{24}$ In the prohibition cases the Supreme Court rejected the contention that the sale of liquor to Indians off the reservation was intrastate commerce which the federal government had no power to regulate. ${ }^{25}$ The Court interpreted the commerce clause as a broad

15. See note 7 supra. ed.).

16. U.S. SOLICITOR FOR THE DEP'T OF INTERIOR, FEDERAI INDIAN LAW 138 (1958

17. Appropriations Act of March 3, 1871, ch. 120, § 1, 16 Stat. 544, 566, 25 U.S.C. $\$ 71$ (1964).

18. Id. For a discussion of Indian treaties in light of recent congressional enactments see Anderson v. Gladden, 188 F. Supp. 666, 676 (D. Ore. 1960).

19. Act of July 22, 1790, ch. 33, 1 Stat. 137; Act of May 19, 1796, ch. 30, 1 Stat. 469; Act of March 30, 1802, ch. 13, 2 Stat. 139; Act of June 30, 1834, ch. 161, 4 Stat. 729.

20. See e.g., Act of July 22,1790 , ch. $33, \S 5,1$ Stat. 137 , 138; Act of June 30, 1834 , ch. 161, §§ 19-22, 4 Stat. 729, 732-33.

21. See, e.g., Act of July 22,1790 , ch. $33, \S \S 1-4,1$ Stat. 137, 137-38.

22. Act of June 30, 1834, ch. 161, \& 24, 4 Stat. 729, 733.

23. Act of March 30, 1802, ch. 13, § 21, 2 Stat. 139, 146.

24. The liquor prohibition, formerly 25 U.S.C. $\$ \S 241-50$, was repealed by Act of June 25, 1948, ch. 645, \& 21, 62 Stat. 683, 862.

25. United States v. Holliday, 70 U.S. (3 Wall.) 407 (1866). 
grant of authority over those who dealt with the Indians, ${ }^{26}$ as well as the Indians themselves, ${ }^{27}$ and not merely over the land the Indians occupied. ${ }^{28}$ The Court upheld the extension of federal sanctions beyond the reservation ${ }^{29}$ and applied them to the sale of alcohol to Indians who had assumed the responsibilities of state citizenship ${ }^{30}$ and who held fee simple title to land they occupied. ${ }^{31}$ This constituted a significant extension of federal power, since the states had traditionally considered Indians who venture off the reservation to be under their jurisdiction. $^{32}$

\section{B. The Guardian-Ward Relation}

The courts, in maintaining that the liquor prohibition applied to Indians not residing on a reservation, recognized a second source of congressional power-that implicit in the "guardianship" of the United States over the Indian ${ }^{33}$ - which operated in conjunction with the constitutional authority of the commerce clause. ${ }^{34}$ The "guardian-ward" theory of federal-Indian relations arose out of a dictuin in Chief Justice Marshall's opimion in Cherokee Nation v. Georgia, ${ }^{35}$ and the federal judiciary has often relied on it as a justification for the exercise of federal power as against both the states ${ }^{36}$ and the tribe. ${ }^{37}$ The theory is based on the relative weakness and dependency of the tribes visá-vis the federal government ${ }^{38}$ and emphasizes the federal govern-

26. Perrin v. United States, 232 U.S. 478 (1914); United States v. Sandoval, 231 U.S. 28 (1913); United States v. Holliday, 70 U.S. (3 Wall.) 407 (1866).

27. See Hallowell v. United States, 221 U.S. 317, 324 (1911).

28. United States v. Forty-three Gallons of Whiskey, 93 U.S. 188, 196 (1876). Such an interpretation of the commerce clause regarding Indians may not appear particularly broad today, in light of the extensive application of Congress' power over interstate commerce. It should be noted, however, that the present interpretation of the power of imterstate conımerce was born out of years of litigation and political pressure. As to Indians, the courts virtually assumed that the commerce clause gave Congress plenary power over Indian affairs. See Worcester v. Georgia, 31 U.S. 350, 379, 6 Pet. 515, 559 (1832).

29. United States v. Forty-thrce Gallons of Whiskey, 93 U.S. 188, 196 (1876).

30. Hallowell v. United States, 221 U.S. 317 (1911).

31. United States v. Sandoval, 231 U.S. 28,48 (1913).

32. For cases involving state jnrisdiction over Indians off the reservation, see, e.g., Petition of Fox, 141 Mont. 189, 376 P.2d 726 (1962); State v. La Barge, 234 Wis. 449, 291 N.W. 299 (1940); Ex parte Moore, 28 S.D. 339, 133 N.W. 817 (1911); Pablo v. People, 23 Colo. 134, 46 P. 636 (1896).

33. See United States v. Holliday, 70 U.S. (3 Wall.) 407, 418 (1866); Hallowell v. United States 221 U.S. 317, 324 (1911).

34. United States v. Holliday, 70 U.S. ( 3 Wall.) 407, 418 (1866).

35. 30 U.S. 1, 9, 5 Pet. 1, 12 (1831): "[The Indians] are in a state of pupilage; their relation to the United States resembles that of a ward to his guardian."

36. United States v. Kagama, 118 U.S. 375, 383 (1886).

37. United States v. Clapox, 35 F. 575, 577 (D. Ore. 1888).

38. Cherokee Nation v. Georgia, 30 U.S. 1, 9, 5 Pet. 1, 12 (1831); United States v. Sandoval, 231 U.S. 28, 48 (1913). 
ment's obligation to aid the Indian in coping with an alien civilization whicl has inexorably altered the Indian's traditional way of life. ${ }^{30}$ The guardianship theory has provided the justification for restraining an Indian from ahenating his land, ${ }^{40}$ for exempting a tribal Indian from a state adultery law, ${ }^{41}$ for establishing a body of criminal law applicable to Indian country, ${ }^{42}$ and for maintaining exclusive jurisdiction over crimes between Indians in Indian country, ${ }^{43}$ as well as providing an additional rationale for the liquor prohibition. ${ }^{44}$

\section{Federal Ownership}

The third source of the plenary power of the United States, the federal "ownership" of Indian land, has served as a complement to the guardianship theory. In Cherokee Nation v. Georgia, Chief Justice Marshall argued that the Indians' dependency upon the federal government-the situation which necessitated the government's guardianship -was a consequence of the fact that the federal government held title to the land they occupied. ${ }^{45}$ The doctrine of federal ownership originated in Johnson \& Graham's Lessee v. McIntosh ${ }^{46}$ where Marshall, in holding invalid a land patent granted by the Cherokee Nation, maimtained that title was in the United States and was derived fron the riglit of discovery exercised by the colonial forerunners of the new nation. According to Marshall, the Indian tribes held only an exclusive right of occupancy. ${ }^{47}$ Much in the way a landlord draws up rules for his tenants, the federal government, as owner of the land on which the Indians live, has declared what laws shall and shall not apply ${ }^{48}$ to its "tenants" on the reservation. The federal landlord niay condition the Indian tenants' use of the land ${ }^{49}$ and even has the right to terminate the Indians' right of occupancy altogether. ${ }^{60}$ The basis of the unique landlord and tenant theory was restated in United States $v$. Kagama ${ }^{\mathrm{b1}}$ when the Suprene Court, in holding that the government's exclusive

39. See Marshall's discussion of the plight of the tribes in the face of the expanding white civilization in Cherokee Nation v. Georgia, 30 U.S. 1, 10-11, 5 Pet. 1, 15-16 (1831).

40. Tiger v. Western Investment Co., 221 U.S. 286 (1911).

41. State v. Campbell, 53 Minn. 354, 55 N.W. 553 (1893).

42. United States v. Kagama, 118 U.S. 375,383 (1886).

43. United States v. Pelican, 232 U.S. 442, 447 (1914).

44. See, e.g., Hallowell v. United States, 221 U.S. 317, 324 (1911).

45. 30 U.S. $1,12,5$ Pet. 1,17 (1831).

46. 21 U.S. (8 Wheat.) 240 (1823).

47. Id. at 261 .

48. See 18 U.S.C. $\$ 1152$ (1964) for the scope of federal law on the reservation.

49. See, e.g., 25 U.S.C. $\& 466$ (1964) (dealing with the conditions on Indian grazing rights).

50. See the discussion of the termination acts accompanying note 124 infra.

51. 118 U.S. 375 (1886). 
jurisdiction over the commission of major crimes ${ }^{52}$ by Indians on the reservation was not an unconstitutional interference with state authority, maintained that the power of the United States over Indian country and other "federal enclaves" emanated from "ownership of the country in which the Territories are, and the right of exclusive sovereignty which must exist in the National Government and can exist nowhere else."53

The latter two sources of federal power-guardianship and ownership-operate together. Where a controversy taking place in Indian country does not involve Indians or Indian interests, as in a crime involving non-Indians on the reservation, the federal judiciary has tended to assume that exclusive federal jurisdiction over the crime does not exist even though the crime is committed on federally owned land. ${ }^{54}$ Apparently the federal landlord will deal exclusively with the persons and property of its Indian tenants, but it does not feel it necessary to deal with controversies that, although arising on federal property, concern only non-Indians.

The potential scope of congressional power over Indian affairs is, as the sources of that power demonstrate, unlimited; but the exercise of congressional power has been restrained both by the federal judiciary's commitment to tribal sovereignty ${ }^{55}$ and by Congress' own imability to determine how it wants to deal with' the Indian and his tribe. ${ }^{56}$ Whereas the Constitution places restraints on congressional power over the states and the individual ${ }^{57}$ in many areas of the law, there is no analogous constitutional restraint on Congress in governing tribal affairs. ${ }^{58}$ State jurisdiction over tribal Indians may be granted or limited by Congress, and the authority of the tribe-indeed the tribe's very existence ${ }^{59}$ - hinges on the sanction of Congress. But the courts have never wholeheartedly accepted the full implication of congressional plenary power; as Part III will demonstrate, they have continued to

52. Listed in 18 U.S.C. $\S 1153$ (Supp. V, 1969) as: murder, manslaughter, rape, carnal knowledge of any female not one's wife, who has not attained the age of sixtcen years, assault with intent to commit rape, incest, assault with intent to kill, assault with a dangerous weapon, assault resulting in serious bodily injury, arson, burglary, robbery, and larceny in Indian country.

53. 118 U.S. at 380.

54. See, e.g., Langford v. Monteith, 102 U.S. 145 (1880); Draper v. United States, 164 U.S. 240 (1896).

55. See Cohen, Indian Rights and the Federal Courts, supra note 6.

56. See Part II infra.

57. See, e.g., U.S. ConST. amends. I-X.

58. While Congress' plenary power over the tribe and over the Indian within the context of the tribal relationship is complete, the individual Indian is also an American citizen and is protected from congressional action which impinges on his constitutionally protected rights as a citizen. See FEDERAL INDIAN LAW, supra note 2, at 91.

59. See, e.g., the acts terminating Indian reservations, discussed in Part II(E) infra. 
operate under the theory that tribal sovereignty and federal plenary power are not inconsistent. Any congressional policy designed to undermine this sovereignty and advance the goals of assimilation has been resisted, although not overtly attacked, by the courts. ${ }^{00}$ The efforts of the courts to mitigate congressional pohicies aimed toward subverting tribal authority have been aided by congressional vacillation between the policies of assimilation and separation because Congress has never been sufficiently committed to any single policy to exercise its plenary power to force the uncompromised execution of the policy. Part II will outline this uncertain pattern of Indian legislation.

\section{II}

THE HISTORICAL DEVELOPMENT OF INDIAN LEGISLATION

As with all other objects of congressional concern, the fate of the Indian las been subject to varying influences: national priorities, the influence of political pressure groups, and the ebb and flow of insight into, and concern with, social problems. Much of the chromic Indian dissatisfaction in the United States is attributable to the conflict between the spasmodic nature of congressional actions and the need for consistency and stability of a people attempting to adapt to an alien social and political environment.

\section{A. Treatymaking and the Recognition of Tribal Sovereignty}

For the first century of the nation's existence, the practicalities of its growth dictated the nature of the relations with the various tribes. The tone was set in the colonial period when the European settlers discovered the Indians could outfight them, thus making negotiated peace highly desirable. ${ }^{61}$ Treatymaking implied the recognition of an Indian group, whether designated tribe or nation, as an independent, sovereign power. The English government's early determination that Indian lands should be acquired either with their permission or by buying title reinforced this characterization. ${ }^{62}$

The treaties made under the Confederation and in the early days of the Union reflected conflicting theories of Indian sovereignty and Indian subordination. The treaty language expressed the arrogance and confidence of the victorious revolutionaries" who "[gave] peace

60. See, e.g., the discussion in Part MI(C) infra, dealing with the judicial response to the assimilationist legislation of the 1880 's.

61. McNickle, Indian and European-Indian-White Relations From Discovery to 1887, 311 Annals 1, 6 (1957).

62. Id. at 4.

63. Worcester v. Georgia, 31 U.S. 350, 373, 6 Pet. 515, 551 (1832). But see Cherokee Nation v. Georgia, 30 U.S. 1, 14, 5 Pet. 1, 20 (1831) (Johnson, J., concurring). 
to all the Cherokees, and receive[d] them into the favor and protection of the United States of America . . . ." later pointed out, in discussing the Hopewell Treaty with the Cherokee, since the Indians signing the treaty in all likelihood did not read or understand Enghish their impression of the relative strengths of the parties to the treaty inay have differed substantially from that connoted by the above language. Marshall suggested that the common provisions of the treaty might be a better indication of the image the two sides had of theinselves and of each other. ${ }^{05}$ The treaty provisions, upon examination, evidence a degree of the superiority so strongly proclaimed in the preamble, but there are also provisions which recognize the limited sovereignty of the Cherokee Nation. Article IX of the Hopewell Treaty ${ }^{60}$ parallels the commerce clause in giving Congress the exclusive right to regulate trade with the Indians, but it goes further. It leaves to Congress the management of "all their affairs in such manner as they ${ }^{67}$ think proper." 68 The United States is also charged with punishment of criminal offenses by or against Indians, but the responsibility of dehivering up offenders is given to the tribe ${ }^{60}$ - a recognition of their dominion within their boundaries..$^{70}$ Six years later, article VIII of the Holston Treaty with the Cherokee further acknowledged Indian power within their territory by declaring that citizens settling on Indian land thereby forfeited the protection of the United States. ${ }^{71}$

Having once recognized the existence of "Indian nations" in the treatymaking process, Congress subsequently began to limit the implications of the initial admission. The 1817 codification of treaty provisions governing law enforcement on Indian lands, for example, extended federal criminal jurisdiction and federal criminal law to of-

64. 7 Stat. 18 (1785).

65. 31 U.S. at 373,6 Pet. at 549.

66. 7 Stat. 18 (1785).

67. Advocates of federal dominance have not questioned that "they" refers to Congress; however, the antecedent is not so clear given the use shortly before of "their" to refer to Indians. See Cherokee Nation v. Georgia, 30 U.S. (5 Pet.) 1 (1832). If "they" had been taken as referring to "Indians" it might have affected the courts' struggle with the concept of Indian "nations." It would at least have indicated a more pervasive acceptance of Indians' right and ability to govern themselves.

68. 7 Stat. at 20.

69. Id. Articles VI and VII, read together, require Indians to deliver up a fugitive, whether Indian or non-Indian, wanted for a crime committed inside or outside the Indians' boundaries.

70. Cherokee Nation v. Georgia, 30 U.S. 1, 40, 5 Pet. 1, 61 (1831) (Thompson, J., dissenting).

71. 7 Stat. 39 (1791). There is a notable absence of arrogant language in this treaty. It repeated the provision for punishment of criminal acts, but not the mention of Congress' exclusive rights to regulate trade and manage Indian affairs. The regulation of trade had by then been incorporated in the Constitution, but the lack of a reference to management of Indian affairs is noteworthy. 
fenses within Indian boundaries. ${ }^{72}$ This assertion of federal dominance was tempered by excepting froin federal jurisdiction any offense coinmitted by one Indian against another on Indian lands. ${ }^{73}$ Thus the Indian's right to self-government was reiterated, while being clearly limited, at least in the area of crimes, to cases in which no non-Indians were involved.

Congressional treatment of the Indians during the early period of treatymaking was not based on any systematic plan or particular policy. Rather, it appeared to be a series of ad hoc solutions to problems created by the circumstances of the mounent with hittle consideration of the solution's potential consequences. This is illustrated by the 1819 act providing for "the civilization of the Indian tribes adjoining the frontier settleinents." This statute, enacted "for the purpose of providing agamst the further decline and final extinction of the Indian tribes . . . and for introducimg annong them the habits and arts of civilization . . .." authorized the President, with the Indians' consent, to employ people to teach Indians the "three R's" and agricultural techniques. ${ }^{75}$ When, in the 1830 's, Congress did eunbark on a systematic effort to separate and preserve the Indian tribes from the states by moving the tribes to land west of the Mississippi, the ad hoc nature of this act became apparent. The success of the earher plan to educate and "civilize" the Cherokee had made thein more attached to their lands ${ }^{76}$ and hence treinendously resistant to being reinoved to the West.

72. Act of March 3,1817, ch. 92, 3 Stat. 383, as amended, Act of June 30, 1834, ch. $161 \S 29,4$ Stat. 734. The House Committee reporting on a later bill containing these same federal jurisdiction provisions noted the exception which accompanied the extension of jurisdiction over the reservation: "It will be seen that we cannot, consistently with the provisions of some of our treaties, and of the territorial act, extend our criminal laws to offenses by or against Indians, of which the tribes have exclusive jurisdiction; and it is rather of courtesy than of right that we undertake to punish crimes committed in that territory by and against our own citizens." H.R. REP. No. 474, 23d Cong., 1st Sess. 13 (1834).

73. Act of March 3, 1817, ch. 92, 3 Stat. 383, as amended, Act of June 30, 1834, ch. $161, \S 29,4$ Stat. 734 .

74. Act of March 3, 1819, ch. 85, 3 Stat. 516. John Marshall later interpreted this act as an expression of a congressional policy: "This act avowedly contemplates the preservation of the Indian nations as an object sought by the United States . . . ." Worcester v. Georgia, 31 U.S. 350, 377, 6 Pet. 515, 557 (1832). This notion served Marshall's purposes at the time, but attributes more uniformity to congressional action than actually existed. See text accompanying note 160 infra.

75. This act gives a foretaste of the separationist and assimilative threads running through the history of United States-Indian relations in its respect for the Indian wishes combined with a desire to "civilize" the Indian. It is remarkable in that the two were not combined again until 1968. See Part II (F) infra.

76. Burke, Thè Cherokee Cases: A Study in Law, Politles, and Morality, 21 StAN. L. REV. 500, 503 (1969). 


\section{B. The Removal Acts and the Policy of Separation}

The first comprehensive program expressive of a national policy toward Indian tribes began in $1830^{77}$ with the enactment of an "Act to provide for the excliange of lands with Indians in any state . . . and for their removal west of the Mississippi." ${ }^{378}$ The separationist philosophy, as implemented in the treaties concluded under the removal acts, was eminently practical, given the priorities of the era. It reflected the tremendous pressures for land exerted by the ever growing body of settlers. $^{79}$ It was also, for the white man, an easy answer to the racial conflict that arose under this pressure. ${ }^{80}$ With such justification, and the belief that it was a permanent solution, ${ }^{81}$ the exchanges of land became an honorable way to avoid dealing with the more difficult and more basic political conflicts of interest inherent in allowing a "sovereign nation" to exist within a state without being incorporated into the federal system.

Inasmuch as Congress believed that the Indians would eventually disappear either as a "nation" or as a recognizable minority, ${ }^{82}$ it was reasonable for the government in 1830 to direct its creative energies to other problems. But the separationist solution encouraged and strengthened the exercise of tribal self-government, ${ }^{83}$ making future conflicts more certain and accominodations more difficult. Although Congress continued to exert its authority over the Indians through such measures as annual appropriations bills and the organization of a bureau

77. In 1828 the government signed a treaty for the removal of Cherokees to Arkansas (7 Stat. 311), but only after the Act of 1830 was the removal policy vigorously pursued: Shawnee (1831) (7 Stat. 355), see note 81 infra; Pottawatamee (1837) (7 Stat. 532); Ohio Indians (1838) (7 Stat. 350); Sac-Fox (1842) (7 Stat. 596).

78. Act of May 28, 1830, ch. 148, 4 Stat. 411.

79. This is in itself a reflection of the attitude that agriculture was a higher use of the land than hunting. McNickle, supra note 61 , at 3 .

80. Id.

81. Few people imagined the broad western expanse would soon be settled. G. FOREMAN, INDIAN REMOVAL $244 \mathrm{n} .33$ (1932). This is reflected in the language of such treaties as that for the removal of the Shawnee in which the United States guaranteed "that said lands shall never be within the boundaries of any state or territory, nor subject to the laws thereof." Treaty with the Shawnees, art. X, 7 Stat. 355 (1831). There can be little doubt that in the 1830's such guarantees, although shortsignted, were given in good faith, even though later treaties might not deserve such generous evaluation.

82. Removal treaties reflected this assumption in provisions like that in the Shawnee treaty granting land "by patent in fee simple to them and their leirs forever, as long as they shall exist as a nation and remain upon the same land ...." (Treaty with the Shawnees, art. II, 7 Stat. 355 (1831)) and im articles specifying that the land was to revert to the United States in case of the disappearance of the tribe.

83. See, e.g., Treaty With the Cherokees, art. V, 7 Stat. 478 (1835), which guaranteed to the Cherokee the right to make and enforce the laws they might deein necessary to the government of their people, limited only by the requirement of consistency with the Constitution and laws of the United States. 
for Indian affairs ${ }^{84}$ with specified supervisory powers, deference to tribal governmental institutions was continuously present. ${ }^{85}$

In 1871, after most of the tribes had been settled on reservations, Congress moved to end the most obvious manifestation of its ambivalent treatinent of Indians. In a paragraph of an appropriations act the practice of making treaties with Indian nations was ended. ${ }^{80}$ From the act's implicit recognition of the problems of maintaining separate Indian groups a short step brought Congress to the assimilative policies embodied in the legislation of the 1880's.

\section{The Shift to Assimilation}

A growing acceptance of assimilationist policy goals had been taking place during the operation of the congressional policies of separation. ${ }^{87}$ Relying for ethical justification on the "white man's burden" and "melting pot" philosophies, ${ }^{88}$ assimilationists advocated the replacement of Indian culture by white civilization. ${ }^{89}$ As the country turned away from regarding the Indian as an alien and began to think in terms of making him a part of American society, the Indian tribe, the primary victim of the tremendous westward expansion of the United States, faced a challenge to its very existence.

The congressional shift away from the separationist policy of the early and middle nineteenth century was triggered by the country's response to the Supreme Court's 1883 decision in Ex parte Crow Dog. ${ }^{90}$ In Crow Dog the Court held that a federal district court lacked jurisdiction to try a Brule Sioux for the murder of a fellow Brule on their reservation because federal law did not apply to crimes between Indians on the reservation. The American public, horrified that an accused murderer was beyond the reach of its courts, ${ }^{01}$ did not agree with the Court's declaration that an Indian must not be tried under a law "which ineasures the red man's revenge by the maxims of the

84. Act of June 30,1864 , ch. 117, 4 Stat. 735 . This bureau was transferred from the War Department to the Department of Interior when it was formed in 1849. Act of March 3, 1849, ch. 118, $\$ 5,9$ Stat. 395.

85. See, e.g., Act of March 27, 1854, ch. 26, § 3, 10 Stat. 269 (recognition and acceptance of Indian tribal criminal jurisdiction over Indian defendants); Treaty with the Cherokee, 14 Stat. 799 (1866) (post Civil War treaty forgiving the Cherokee for their participation on the Confederate side; detailing political institutions which would be set up to enable the Cherokee to govern their territory).

86. Act of March 3, 1871, ch. 120, 16 Stat. 544.

87. See H. Fritz, The Movement for Indian Assimilation, 1860-1890, at 34-55 (1963). 12 (1957).

88. Haas, The Legal Aspects of Indian Affairs from 1887 to 1957, 311 ANNaLs

89. Federal Indian Law, supra note 2, at 208.

90. 109 U.S. 556 (1883).

91. Federal Indian Law, supra note 2, at 78. 
white man's morality." ${ }^{\text {2 }}$ Congress reacted to the furor by passing, in 1885, the Major Crimes Act, ${ }^{93}$ which gave federal courts criminal jurisdiction over certain offenses even between Indians..$^{94}$

In an apparently contradictory provision, the 1890 act establishing a temporary government for the Oklahoma Territory reserved to Indian judicial tribunals exclusive jurisdiction over civil and criminal cases in Indian country involving only members of the Indian nation. ${ }^{95} \mathrm{Al}-$ though this confirmation of the Cherokee courts' exclusive jurisdiction contrasted with other legislation of the period which was deliberately breaking up tribal institutions, ${ }^{96}$ the spirit of the measures was not inconsistent. The Clierokee and the other "civilized tribes" had long been noted for their successful adaptation to non-Indian ways. Encouragement of their development did not, therefore, require the destruction of tribal relationships which stood as a formidable barrier to "civilization." Rather, common sense called for reinforcennent of the structure that had enabled them to develop, to the extent they had, institutions which were strongly non-Indian in character.

The most significant assimilative legislation of the nineteenth centure was the General Allotment Act of 1887.97 The Act authorized the President, when he deemed it appropriate, to divide a reservation into parcels which would then be allotted in severalty to the individual meinbers of the tribe. For 25 years the Government would hold the parcels in trust for the allottees. At the end of the trust period, which was extendable at the President's discretion, the land would be patented to the Indian allottee. He would then become a citizen subject to the state's jurisdiction. The land in excess of that needed for the allotments was "surplus" to be made available to non-Indians. Congress thought allotment would break up tribal life, thus exposing Indians to the influence of white civilization. Since the issuance of the patents was to make thein citizens and bring them under state jurisdiction, allotment would also permit them to partake of civilization's benefits. Another aim was to give the Indians more security in their land holdings than tribal possession was thought to afford. ${ }^{98}$ Of course, the law was to benefit non-Indians as well, both by opening up the surplus lands and by relieving the Government of the great expense

92. 109 U.S. at 571.

93. Act of March 3, 1885, 18 U.S.C. \& 1153 (1964).

94. See note 52 supra.

95. Act of May 2, 1890, ch. 182, \& 30, 26 Stat. 81.

96. See, e.g., General Allotment Act, ch. 119, 24 Stat. 388 (1887), as amended, 25 U.S.C. $\S \S 331-416 j$ (1964).

97. Id.

98. Federal Indian Law, supra note 2, at 208. Some Indians favored allotment for this reason, but most apparently preferred the traditional system of tenure in common. 
of Indian annuities and other services. The land division clauses were primarily concerned with facilitating non-Indian absorption of the land; 90 the citizenship and state jurisdiction clauses were more clearly assimilative devices, although they undoubtedly grew out of equally mixed motives. ${ }^{100}$ In practice, the most significant impact of the allotment scheme was the loss to the Indians of over 90 million acres of land which they had held prior to the Allotinent Act and the resultant demoralization of the Indian population. ${ }^{101}$

\section{The Wheeler-Howard Act and the Renaissance of Tribal Goverment}

The Allotinent Act dominated Indian affairs until 1934 when the Wheeler-Howard Indian Reorganization Act $^{102}$ reversed the trend toward assimilation. The Act, which was intended "to conserve and develop Indian land and resources" brought to an end the practice of allotment, provided for the restoration of surplus lands, and empowered the Secretary of the Interior to acquire lands for the Indians. ${ }^{103}$ Senator Wheeler, one of the bill's sponsors, described one of the purposes of the bill as being "To stabilize the tribal organization . . . with real, though limited, authority, and [to prescribe] conditions which must be met by such tribal organizations."104 President Roosevelt actively supported the bill because it allowed "the Indian people to take an active and responsible part in the solution of their own problems."105 The Act restored land to tribal ownership ${ }^{108}$ and provided for tribal self-government under tribal constitutions. ${ }^{107}$ The requirement that the constitutions be subject to tribal ratification ${ }^{108}$ evidenced the federal

99. Id. at 209. Cohen admits the greatest pressure for allotment came from landhungry settlers, probably in alliance with the railroads.

100. In contrast, the 1820 Georgia statutes which precipitated the Cherokee Nation litigation (see Part III(A) infra) did not have an assimilative intent though they gave that impression. Rather the state wanted to pressure the Indians into inoving west. G. ForEMAN, supra note 81 , at 235.

101. BROPHY \& ABERLE, supra note 1, at 20.

102. Act of June 18, 1934, ch. 576, §§ 1-18, 48 Stat. 984, 25 U.S.C. $\S \$ 461-79$ (1964).

103. See also Act of June 20, 1936, ch. 622, 49 Stat. 1542 (relief of Indians' lauds from restrictions for failure to pay taxes).

104. S. ReP. No. 1080, 73d Cong., 2d Sess. 1 (1934).

105. Roosevelt's letter to the sponsors of the bill, in H.R. REP. No. 1804, 73d Cong., 2 d Sess. 8 (1934).

106. Act of June 18, 1934, ch. 576, § 1, 48 Stat. 984, 25 U.S.C. § 461 (1964).

107. Id. $\S 16,25$ U.S.C. $\S 477$ (1964). Section 16 provided that a tribe could organize for the common welfare by adopting a constitution and by-laws.

108. Id. The Act also provided that a tribe could incorporate by vote of the adults on the reservation. There were provisions for increased educational and employment opportunities and for a revolving loan fund to be admimistered by the tribe. See 25 U.S.C. $\S \$ 461-479$ (1964). 
government's desire to reduce federal responsibility over Indian affairs by allowing the Indians themselves to significantly affect the shape of their own future. ${ }^{109}$

The effort to reduce federal dominance over Indian affairs implicit in the legislation of the Roosevelt administration also affected the operations of the Bureau of Indian Affairs (B.I.A.). As tribal institutions had grown weaker during the allotment period, the administrative authority of the B.I.A. had expanded to fill the void. ${ }^{110}$ Thus, notwithstanding a congressional policy designed to promote Indian self-sufficiency, the Bureau had assumed nearly absolute control over reservation Indians. ${ }^{111}$ The Wheeler-Howard Act was designed to reduce the need for Bureau administrative activities and, ultimately, to curtail its authority. ${ }^{112}$ Other acts of the period were aimed at reducing Bureau involvement in such areas as health care, education, agricultural assistance and social welfare, ${ }^{113}$ federal restrictions on civil liberties, ${ }^{114}$ and Bureau discouragement of Indian customs and practices. ${ }^{115}$ The B.I.A. proved highly resiliant, however, and the Indian New Deal did not succeed in substantially curtailing the power of the Bureau over the hives of Indians. ${ }^{116}$

The legislation of the Roosevelt administration attempted to strengthen tribal institutions and Indian identity-predominantly separationist aims. To the extent federal witldrawal opened the door to state involveinent instead of Indian control, however, the Indian New Deal laid the foundation for the highly assimilative programs of the 1950's.

109. This attempt to involve Indians in decisionmaking appeared again in the Indian Civil Rights Act of 1968. See Part II(F) infra.

110. Haas, supra note 88 , at 16 . One commentator has suggested that the more oppressive actions of the B.I.A. during the allotment period were consciously designed to make reservation life sufficiently odious to entice reservation Indians to take allotments and thereby escape such oppression. Cohen, Indian Rights and the Federal Courts, 24 MINN. L. Rev. 145, 189-90 (1940).

111. Federal Indian LaW, supra note 2, at 175.

112. Zimmerman, The Role of the Bureau of Indian Affairs Since 1933, 311 ANNALS 31, 33 (1957).

113. Act of April 16, 1934, ch. 147, 48 Stat. 596, 25 U.S.C. $\$ \$ 452-54$ (1964); Federal Indian Law, supra note 2, at 83 . The first step toward reducing federal control in these areas was taken in 1929 with a statute which allowed state inspection on the reservation. Act of Feb. 15, 1929, ch. 216, 45 Stat. 1185, as amended, Act of Aug. 9, 1946, ch. 930, 60 Stat. 962, 25 U.S.C. $\$ 231$ (1964). The process was completed in 1954 with the transfer of Indian health services to the United States Public Health Service in the Department of Health, Education, and Welfare. Act of Aug. 5,1954, ch. 658,68 Stat. 674,42 U.S.C. $\S \S 2001-04 a$ (1964).

114. Act of May 21, 1934, ch. 321, 48 Stat. 787; see FeDERAI Indian Law, supra note 2 , at 175 .

115. Act of August 27, 1935, ch. 748, 49 Stat. 891, 25 U.S.C. $\$ \S 305-05 e$ (1964). See Federai Indian IAW, supra note 2, at 87.

116. See generally Zimmerman, supra note 112 . 


\section{E. Termination}

In 1953 Congress once again returned to the policy of assimilation. The assimilative intent of Congress was expressed in House Concurrent Resolution 108, passed August 1, 1953, ${ }^{117}$ which stated that

$[I] t$ is the policy of Congress, as rapidly as possible, to make the Indians within the territorial limits of the United States subject to the same laws and entitled to the same privileges and responsibilities as are applicable to other citizens of the United States ... and to grant then all of the rights and prerogatives pertaining to American citizenship ....118

Two weeks later this intent was evidenced by Public Law $280^{110}$ which extended certain states' jurisdiction over civil and criminal cases in Indian country ${ }^{120}$ and allowed any other states wishing to assume jurisdiction over Indian country to do so by coinplying with certain procedures. ${ }^{121}$ The status of tribal self-government suffered with the extension of state jurisdiction to the reservation in that tribal ordinances were only effective insofar as they did not conflict with state law. The committee report on the act stated the intention of Congress to withdraw federal resonsibihity for Indian affairs wherever practicable. ${ }^{122}$ The committee asserted as a justification for the transfer of criminal jurisdiction the inadequacy of soine tribes in dealing with the law and order responsibilities left thein by the federal government. This inadequacy resulted in a hiatus in enforcement for which state involvement was the best remedy. It also stated that the transfer of civil jurisdiction was desirable in light of the stage of acculturation reached by Indians in certain states. ${ }^{123}$

The assimilative trend reacled its zemth in the termination program of 1954. Congress passed a series of acts which provided for the withdrawal of all federal services and B.I.A. employees upon completion of plans for termination of the Indian reservations. ${ }^{124}$ The

117. H.R. Con. Res. 108, Aug. 1, 1953, 67 Stat. B132.

118. Id.

119. Act of Aug. 15, 1953, ch. 505, 67 Stat. 588, amending 18 U.S.C. $\S \S 1151$, 1162,28 U.S.C. $\$ \S 1331,1360$.

120. Id.

121. "Notwithstanding the provisions of any Enabling Act for the admission of a State, the consent of the United States is hereby given to the people of any State to amend, where necessary, their State constitution or existing statutes, as the case may be, to remove any legal impediment to the assumption of civil and criminal jurisdiction in accordance with the provisions of this Act ..." Act of Aug, 15, 1953, ch. $505 \S 6,67$ Stat. 588 .

122. H.R. REP. No. 848, 83d Cong., 1st Sess. 3-8 (1953).

123. Id. at 6 .

124. Act of June 17, 1954, ch. 303, 68 Stat. 250, 25 U.S.C. $\$ \$ 891-901$ (1964) (Menominee); Act of Aug. 13, 1954, ch. 732, 68 Stat. 718, 25 U.S.C. $\S 564$ (1964) (Klamath); Act of Aug. 23, 1954, ch. 831, 68 Stat. 768, 25 U.S.C. § 721 (1964) 
termination acts represented the lowest ebb of congressional esteem for the tribal organization since the Allotment Act; they were directed toward putting an end to the tribal relationship itself. The acts provided four alternative methods for the distribution of all real and personal property held by the government for the designated tribes:125 First, the tribe could control its land as a corporation chartered by state law; second, the land could be held in trust for the Indians by qualified trustees; third, the land could be sold, the proceeds to be divided among the tribal menners; or fourth, the reservation could be divided into parcels, each tribal member receiving an allotment. ${ }^{128}$

The acts forced the Indian into the inainstream of American life by eliminatimg the special status he had traditionally been accorded by the United States. The concept of federal guardianship and the paternalistic policies it had engendered had proved a burden to the Indian by placing restrictions on his land and his person and a burden upon the federal government by obligating it to allocate funds and personnel to administer Indian affairs. A charitable attitude toward the termination policy requires the assumption that it was designed to eliminate the burden on the Indian as well as the burden on the federal government, but a realistic appraisal of the policy nuust include the additional consideration of whether it is feasible to assimilate, en masse, a very different culture into the American inainstream.

\section{F. The Indian Civil Rights Act: The Last Chapter?}

The strong negative reaction of Indians everywhere, even those not immediately involved, coupled with changes in administration, has resulted in a retreat from the totally assimilative policy of the Termination Acts. ${ }^{127}$ The current trend is toward increasing congressional awareness of the conflicts that were perpetuated by previous congressional inattention and the continued separate existence of Indian tribes. ${ }^{128}$ The Indian Civil Rights Act of $1968,{ }^{129}$ the inost recent

(Texas tribes); Act of Sept. 1, 1954, ch. 1207, 68 Stat. 1099, 25 U.S.C. $\$ \S 741-60$ (1964) (Paiute).

125. There were variatious in detail among the three acts, the most unuual being that the Texas lands were transferred to the state to hold in trust for the Indians. Act of Aug. 23, 1954, ch. 831, 68 Stat. 768.

126. See, e.g., Paiute Termination Act of Sept. 1, 1954, ch. 1207, 68 Stat. 1099, 25 U.S.C. $\S \S 741-60$ (1964). But see Act of Aug. 23, 1954, ch. 831. 68 Stat. 769.

127. In his July 8, 1970 address to Congress on Indian affairs, President Nixon requested that Congress repeal H.R. Con. Res. 108 (see text at note 117 supra) and make clear that termination will no longer be a goal of either the legislative or the executive branch of the federal governmeut. Indian Affairs, The President's Message to the Congress, 6 Weeriy Compination of Presidentual Documents 894, 895-96 (1970).

128. See text accompanying note 79 supra. 
legislation affecting Indians, appears to be a compromise between separationist and assimilative policies.

The Act, while providing for some degree of self-government, places a number of constitutional restrictions on its exercise. The Act replaced the "separate standard" which the Supreme Court had applied with regard to Indian constitutional rights within the tribal context $^{130}$ with one substantially ${ }^{131}$ the same as that applied to the state and federal governments with regard to the rights of other American citizens. It prohibits tribal governments from interfering witl Indians' exercise of basic civil liberties: freedom of religion, ${ }^{132}$ freedom of speecli, freedom of the press, the right of assembly, and the right to petition the tribal government. ${ }^{133}$ The Act also applies the requirements of due process ${ }^{134}$ to tribal governments; forbids unreasonable search and seizure, ${ }^{135}$ bills of attainder, and ex post facto laws; ${ }^{130}$ and finally, provides protection against double jeopardy. ${ }^{137}$

Assuring Indians of the constitutional rights secured to other Americans is assimilative since it requires at the very least modification of tribal court practices and thus may conflict witli traditional values. ${ }^{138}$ At the same time, the Act recognizes the "quasi-sovereign"130 status of the tribe with residual powers of self-government. ${ }^{140}$ Other antiassimilationist provisions in the Indian Civil Rights Act were the revision of Public Law 280 to require a tribe's consent before a state could assume jurisdiction over it, and the expression of congressional willingness to have states return previously assumed jurisdiction to the federal government. ${ }^{141}$ It could be the intent of the Act to strengthen tribal institutions while achieving greater conformity witl national stand-

129. Act of April 11, 1968, Pub. L. No. $90-284,82$ Stat. 77, 25 U.S.C. $\$ \S 1301$ 41 (Supp. V, 1969).

130. See text accompanying note 187 infra.

131. See Hearings on H.R. 15419 and Related Bills Before the Subcomm. on Indian Affairs of the House Comm. on Interior and Insular Affairs, 90th Cong., 2d Sess., ser. 23 at 37 [hereinafter cited as Hearings on H.R. 15419]. The Act does not incorporate the entire Bill of Rights. In light of the length and comprehensiveness of congressional investigations on the various bills proposed, it may be assumed that the areas not expressly imcluded were intended to be left to tribal custom and law.

132. 25 U.S.C. $\$ 1302(1)$ (Supp. V, 1969). The Act does not, however, prevent the tribe from establishing a religion; such a prolibition would, for example, destroy the basis for Pueblo Indian society which is heavily dependent on a single religion.

133. Id.

134. Id. \$§ 1302(5), (6), (8), (10).

135. Id. $\S 1302(2)$.

136. Id. \& 1302(9).

137. Id. \&1302(3).

138. See note 131 supra.

139. See Hearings on H.R. 15419, supra note 130, at 16.

140. 25 U.S.C. $\$ 1302$ (Supp. V, 1969).

141. Id. $\S \S 1321-26$. 
ards for governmental behavior, especially in the administration of justice. ${ }^{142}$

Over the 200 years of its relations with Indians, Congress has followed a vacillating path between separation and assimilation. None of its efforts has been successful in overcoming the initial conceptual problem of conflicting political characcrizations of Indian tribes. The conceptual block has in turn prevented the development of adequate programs to deal with the more fundamental and increasingly coinplex social and economic quandary of the modern Indian. Until Congress recognizes that its incessant policy changes work great injustice on the Indian, the Indian can have little hope of a remedy for his present unhappy condition. President Nixon emphasized the need for consistent policy goals in addressing Congress on his recommendations for legislation to aid Indian self-determination:

In place of policies which oscillate between the deadly extremes of forced termmation and constant paternalism, we suggest a policy in which the Federal government and the Indian community play complementary roles. ${ }^{143}$

The President's recommendations, which include a repudiation of termination and the institution of Indian control of federally funded programs, may ultimately enable the Indian to effectively shape his own future. Hopefully, the Executive Branch's interest in self-determination will lead to the concrete results which have eluded the Indian people throughout many years of federal programs and promises.

\section{III}

\section{THE JUDICLAL RESPONSE}

The reaction of the federal judiciary, most particularly the Supreme Court, to the problems of the Indians, whether or not arising directly out of a tribe's relations with Congress, has been of a different character from that of Congress. Unlike Congress, the courts have at least attempted to confront and deal with the conceptual problem of the status of the tribe, and at the same time they have lent a degree of consistency to Indian law in the face of continually changing congressional policies.

\section{A. The Beginning of the Judicial Theory of Tribal Sovereignty}

John Marshall, the master builder of constitutional law, laid the

142. See 'Hearings on H.R. 15419 , supra note 130 , at $36 ; 25$ U.S.C. $\S 1311$ (Supp. V, 1969) (authorizing the Secretary of the Interior to draft a model code of tribal justice).

143. Indian Affairs, The President's Message to the Congress, 6 WeEkLY COMPILATION OF PREsIDENTIAL Documents 883, 905 (1970). 
foundations of Indian law precedent. In the early days of the Republic, when legislative patterns were dictated by practical pressures, with little theoretical or philosophical guidance, ${ }^{144}$ the Marshall Court, itself an object of political controversy, attempted to delineate the definitional parameters of many areas of constitutional law. Although the Court was not free of political pressures even on the subject of Indian law, ${ }^{145}$ it grappled with some of the problems Congress would manage to sidestep for over 100 years. Its success, or lack of it, in evolving clear distinctions and principled methods of handling Indian problems lias colored decisions down to the present.

The multiple opinions in Cherokee Nation v. Georgia ${ }^{140}$ anticipated, in 1831, the lines along which future battles would be fought. Georgia had passed a series of statutes in 1829 and 1830 mcorporating Indian lands into existing counties, forbidding the Cherokee to engage in political activities, and asserting control over who could nnove into or through the area. The Cherokee wished the Supreme Court to assert its original jurisdiction as between a state and a foreign nation to prevent Georgia from asserting and exercising control over Cherokee territory. Marshall's opinion for the majority approved the argument that the Cherokee Nation was a "state" and lad been so treated by the United States in its treaties with the Indians. But, he went on to say, it was not a state of the union, nor a foreign state in the constitutional sense. As a territory within the United States boundaries, acknowledged by the rest of the world to be within her jurisdiction and under her protection, it was in a unique third category: a "domestic dependent nation."147 This third category, the Court held, did not come under its original jurisdiction. ${ }^{148}$ The United States has been groping ever smce toward a solution to the problems created by having a third category in the midst of its two-tiered federal system.

The three other opinions in the Cherokee Nation case ${ }^{140}$ outlined soine of the arguments which would recur in later Indian cases. Justice Jolinson found that the Cherokee Nation might be deeined a state only in the sense that "their right of personal self-government [had] never

144. See text accompanying note 74 supra.

145. See Burke, note 76 supra. The Indians have continued to be a political football down to the present day. Abbott, American Indian, Federal Citizen and State Citizen, 20 FED. B.J. 248, 250 (1960). But at no time since 1832 have the courts been directly subjected to such tremendous national pressures over Indian questions.

146. 30 U.S. (5 Pet.) 1 (1831).

147. Id. at 12,5 Pet. at 17.

148. The holding in Cherokee Nation is now irrelevant, but Marshall's description of the tribe has proved to be very significant dictum. See, e.g., United States v. Kagama, 118 U.S. 375,383 (1886).

149. Johnson and Baldwin, JJ., concurring; Thompson, J., dissenting. 
been taken from them." 150 Justice Baldwin denied that the Indians had any inherent right to regulate their internal affairs, attributing the continued exercise of that power to congressional reluctance "to exercise the sole and exclusive right, declared and asserted in all their regulations ...."151 $\mathrm{He}$ also foresaw the difficulties that would arise if the courts recognized another sovereign power existing in competition with the states within their boundaries. ${ }^{152}$

Justice Thompson, dissenting, would have assumed jurisdiction as over a foreign state. He argued that since the Cherokee Nation had been a sovereign state ${ }^{153}$ before the European intrusion, it did not lose its national character simply by binding itself, though in an unequal alliance, with a more powerful state. If Indians had rights enforceable in a court they must be granted access to the Supreme Court as a foreign nation. Thompson had no doubt that the Indian treaties created enforceable rights. ${ }^{154}$

Marshall's opimion a year later in a second Cherokee case, Worcester v. Georgia ${ }^{155}$ evidenced the Court's acceptance of the sovereignty of the tribe which underlay Thompson's dissent in Cherokee Nation v. Georgia, ${ }^{156}$ and it offered the first judicial affirmation of the federal government's plenary power over Indian affairs. Georgia had convicted a Vermont missionary of continuing to reside in Indian territory without the state's permission in violation of the same Georgia statutes. ${ }^{157}$ The majority of the Court had no trouble holding the Georgia statutes unconstitutional on the grounds that they interfered with the relations between the United States and the Cherokee, a nnatter allotted to the federal government by the Constitution. ${ }^{158}$ Marshall thus established the sigual primciple of Indian law: the federal governments plenary power over Indian relations precludes the exercise of state power.

Having decided the case on an embryonic preemption theory, Marshall went on to affirm in dictum a second principle: that the Indian tribes themselves, under the laws and treaties of the United States, possessed a residual ${ }^{159}$ sovereignty with which the states could

150. 30 U.S. at 17,5 Pet. at 27.

151. Id. at 27,5 Pet at 40.

152. Id. at 31,5 Pet. at 47.

153. His definition of a sovereign was any body of persons governing themselves in any form. Id. at 35,5 Pet. at 53 .

154. Id. at 49,5 Pet. at 74.

155. 31 U.S. 350,6 Pet. 515 (1832).

156. Burke, supra note 76 , at 533 .

157. See text accompanying note 144 supra.

158. 31 U.S. at 376,6 Pet. at 560. Presumably the Court meant U.S. CoNsT. art. I, § 8, cl. 3 .

159. 30 U.S. at 12,5 Pet. at 17. 
not interfere. ${ }^{160}$ Marshall characterized the Indian nations as "distinct political communities, having territorial boundaries, within which their authority is exclusive, and having a right to all the lands within those boundaries, which is not only acknowledged, but guaranteed by the United States."161 As a consequence of this unique quasi-sovereignty of the Indian tribe within the federal structure the states could not exercise their own sovereignty inside the boundaries of the Indian nation. The Georgia statutes were repugnant to the laws of the United States because they were "in direct hostility with treaties . . . which ... recognized the pre-existing power of the [Indian] nation to govern itself." 162

For the next 50 years the Court's apphications of Marshall's two principles complenented Congress' separationist prograin of renıving Indian tribes west of the Mississippi. ${ }^{163}$ The decisions affirnıed the Indian exercise of control over their own affairs ${ }^{104}$ and reasserted the federal preemption of state action in the area of Indian regulation. ${ }^{105}$

\section{B. The Judicial Response to Assimilation}

The Supreine Court was very active in the area of Indian law froin the 1880's to the 1930's, the period corresponding to Congress' assimilationist allotment program. ${ }^{106}$ The many encroachments on tribal sovereignty in those years reflected the nation's growing impatience with the Indians as territorial and human obstacles to expansion. State jurisdiction, so vigorously rejected by Marshall, gradually extended into reservation areas. For example, in Langford v. Monteith $^{167}$ the Court recognized the power of an Idaho justice court to rule in a detamer action between two non-Indians over possession of buildings and grounds on a reservation. Similarly in the area of criminal law, the Court acknowledged that the states' jurisdiction extended - to the exclusion of federal jurisdiction-to a non-Indian committing an offense against another non-Indian on a reservation. ${ }^{108}$ These decisions, although allowing the states to breach the territorial himits of the reservations, did not, however, infringe on Indian self-government

160. See 31 U.S. at 392, 6 Pet. at 581 (McLean, J., concurring).

161. Id. at 393,6 Pet. at 582 .

162. Id. at 380,6 Pet. at 562 .

163. Id. at 380, 6 Pet. at 561. See also Part II (B) supra.

164. See, e.g., Mackey v. Coxe, 59 U.S. (18 How.) 100 (1855) (Cherokee laws "relative to estates and administrators" controlling in a claim by heirs against administator's surety).

165. See, e.g., The Kansas Indians, 72 U.S. (5 Wall.) 737 (1866) (Indians free froin state taxation as long as they lived under a treaty).

166. See Part II(C) supra.

167. 102 U.S. 145 (1880).

168. United States v. McBratney, 104 U.S. 621 (1881). 
since they were limited to situations involving only non-Indians.

It took a direct confrontation between the Court and Congress, in 1883, before the Court reacted to the change in congressional attitude that had been slowly surfacing since the Civil War. Crow Dog, a Sioux Indian, was convicted in federal district court of inurdering a fellow Sioux on the reservation. The Supreme Court unanimously held in Ex parte Crow Dog ${ }^{169}$ that the federal court was without jurisdiction. In his opinion for the Court, Justice Matthews stated:

to uphold the jurisdiction exercised in this case, would be to reverse in this instance the general policy of the government towards the Indians, as declared in many statutes and treaties, and recognized in many decisions of this court, from the beginning to the present time. To justify such a departure, in such a case, requires a clear expression of the intention of Congress, and that we have not been able to find.170

Congress soon remedied its failure to make its changed objectives explicit by passing the Major Crimes Act. ${ }^{171}$ The Court immediately acknowledged the new policy by finding the Act constitutional and upholding federal jurisdiction in United States $v$. Kagama, ${ }^{172}$ a murder case much like Crow Dog.

When faced with the clear mandate of the Major Crimes Act the Supreme Court was forced to subordinate its opposition to assimilationist pohicies and accede to congressional will. The Kagama court did, however, have some latitude in qualifying its acceptance of congressional pohcy. The Court reiterated the Indians' "semi-independent position ... not as possessed of the full attributes of sovereignty, but as a separate people, with the power of regulating their internal and social relations. . . ."173 The Court made clear that the jurisdiction in question was federal alone ${ }^{174}$ and that these "semi-independent" people would remain separate from state authority:

$[T]$ he offense under the statute .... [D] oes not interfere with the process of the State courts within the reservation, nor with the operation of State laws upon white people found there. . . . They are communities dependent on the United States. ... They owe

169. 109 U.S. 556 (1883).

170. Id. at 572. Although he could not find a clear expression of the shift in congressional intent, some suspicion of it must have come to him as he strained the language in the 1868 treaty with the Sioux, in the 1871 act ending the practice of treatymaking, and in the act creating the Sioux reservation in 1877 , in order to deny federal jurisdiction. See id. at 565-69.

171. Act of March 3, 1885, ch. 341, 99,23 Stat. 385; as amended, 18 U.S.C.

$\S 1153$ (Supp. V, 1969). See discussion in Part II(C) supra.

172. 118 U.S. 375 (1886).

173. Id. at $381-82$.

174. Id. at 383 . 
no allegiance to the States, and receive from them no protection. Because of the local ill feeling, the people of the States where they are found are often their deadliest enemies. ${ }^{175}$

While upholding the Major Crimes Act-a statute calculated to limit tribal jurisdiction ${ }^{176}$ - the Kagama Court spoke of the federalIndian relationship in language reminiscent of Marshall's earlier opinions in the cases involving the Cherokee Nation's atteinpts to protect its sovereignty froin incursions by the state of Georgia:

These Indian tribes are the wards of the nation . . . . From their very weakness and helplessness, so largely due to the course of dealing of the Federal Government with them and treaties in which it has been promised, there arises the duty of proteetion, and with it the power. ${ }^{177}$

This notion that the government needed to compensate for the immoral taint on its relations with the Indians provided an additional rationale for the Court in its efforts to mitigate the impact of assimilative legislation.

In United States $v$. Nice, ${ }^{178}$ a hiquor prohibition case arising during the height of the assimilationist policies of the early twentieth century, the Court returned to its position in Crow Dog. The case involved the question of whether the General Allotment Act, in giving each member of a tribe his own piece of land, ${ }^{170}$ was meant to dissolve his tribal relations immediately. ${ }^{180}$ The Court agreed that this was a decision for Congress, ${ }^{181}$ but in interpreting the Act, it refused to "lightly infer" that Congress intended such a radical departure from its previous policies as would be involved in saying that allotment alone immediately dissolved tribal relations and eliminated federal guardianship. The Court was aided in reaching this result by the cardinal rule of construction for Indian legislation: that all acts are to be interpreted in favor of the Indians. ${ }^{182}$

The Court's resistance to integrating Indians into the American political system was apparent in the first Supreme Court case presenting

175. Id. at $383-84$.

176. See United States v. Whaley, 37 F. 145 (C.C.S.D. Cal. 1888) (Major Crimes Act foreclosed tribal jurisdiction over the named offenses).

177. 118 U.S. at $383-84$.

178. 241 U.S. 591 (1916).

179. See discussion in Part III(C) infra.

180. If the tribal relation had been dissolved, presuniably the federal prohibition of the sale of intoxicants would not be applicable to the individuals and land in question. See 241 U.S. at 598. See also Perrin vे. United States, 232 U.S. 478 (1914) (liquor laws apply to land ceded by Indians under the Allotment Act).

181. 241 U.S. at 598. See also United States v. Sandoval, 231 U.S. 28 (1913) (whether the hiquor law applied to the pueblos).

182. 241 U.S. at 599. 
a question of Indians' constitutional rights. ${ }^{183}$ In Talton $v$. Mayes, ${ }^{184}$ decided in 1896, an Indian convicted in a Cherokee Court ${ }^{185}$ of an onreservation murder applied for a writ of habeas corpus claiming that the grand jury which indicted him did not meet constitutional standards. Emphasizing the Cherokee's guaranteed right of self-government, the Court said murder between Cherokees is "not an offense against the United States, but an offense against the local laws of the Cherokee nation."186 Because the Cherokee's powers of government were not created by the federal government but were inherent in the Cherokee nation, their laws and methods of enforcement were not brought under the constitutional limitations imposed on the federal and state governments. ${ }^{187}$ Thus, in the middle of the congressional drive to break down tribal institutions, the Court made an important reassertion of two basic anti-assimilationist doctrines: that Indians have always had inherent sovereiguty, and that Indians, as a separate community, are to be held to a different standard than the rest of the country. ${ }^{188}$

\section{The Court and the Allotment Scheme}

During the allotment period the federal courts attempted to reaffirm Marshall's principles, recognizing tribal sovereignty in the face of congressional and administrative policies designed to break up the tribal unit. ${ }^{189}$ The courts protected tribal sovereignty over many areas of Indian affairs, ${ }^{100}$ and did not allow the assimilationist thrust of the

183. No other Supreme Court opinion dealt with the question. Now it is a matter of interpreting and applying the Indian Civil Rights Act of 1968. See Part II (F) supra.

184. 163 U.S. 376 (1896).

185. This case arose in a Cherokee Court because Congress had exempted the Five Civilized Tribes from the Major Crimes Act when it organized the Oklahoma Territory. Act of May 2, 1890, ch. 182, § 30, 26 Stat. 81.

186. 163 U.S. at 381 .

187. Id. at $382-83$.

188. The Court saw the tribe as the clear source of the standard in the absence of explicit legislation to the contrary. The groundwork for the Talton recognition of the separate standard for Indians had been laid in 1884, in Elk v. Wilkins, 112 U.S. 94 (1884), where the Court stated that "General acts of Congress did not apply to Indians, unless so expressed as to clearly manifest an intention to include them." Id. at 100. However, recent cases decided after the advent of Indian citizenship have eroded much of the rule of Elk v. Wilkins. See, e.g., Superintendent of Five Civilized Tribes v. Commissioner, 295 U.S. 418 (1935); FPC v. Tuscarora Indian Nation, 362 U.S. 99 (1960); Navajo Tribe v. NLRB, 288 F.2d 162 (1961).

189. See Part II(C) supra.

190. See, e.g., Jones v. Meelian, 175 U.S. 1 (1899) (tribal authority over inheritance); Standley v. Roberts, 59 F. 836 (8th Cir. 1894) (authority of tribal courts); United States v. Quiver, 241 U.S. 602 (1916) (tribal authority over domestic relations); Buster \& Jones v. Wright, 135 F. 947 (8th Cir. 1905), appeal dismissed, 203 U.S. 599 (1906) (power of Creek Nation to tax those doing business within its territory). 
Allotment Act to undermine tribal authority on reservations that had not been allotted. ${ }^{191}$ The courts contimued to emphasize the Indian's special ward status and in so doing reaffirmed the federal plenary power-and its corollary of state exclusion-in the area of Indian affairs. ${ }^{192}$ Given the congressional policy of assimilation at the time, coupled with continued recognition of tribal sovereignty by the courts, it was surprising that there was only one major case, Lone Wolf $v$. Hitchcock, ${ }^{193}$ directly challenging the exercise of congressional power in allotting tribal land.

The fact that the 1903 opinion in Lone Wolf bears httle resemblance to the opinions which preceded it and followed it is perhaps a reflection of the awkwardness of the Court's position in the case. In Lone Wolf the confederated tribes of Kiowa, Comanche, and Apache Indians challenged the constitutionality of a special act ${ }^{194}$ subjecting their lands to allotment. The challenge was based on the Medicine Lodge Treaty of $1867^{195}$ which provided that no treaty for the cession of Kiowa and Comanche ${ }^{196}$ land would be valid without a three-fourths vote of the adult males of the tribe. ${ }^{197}$ The Supreme Court upheld the act as a proper exercise of Congress' plenary power, noting that "The [appellants'] contention . . . ignores the status of the contracting Indians and the relation of dependency they . . . bear towards the government of the United States."198 The Court distinguished previous cases in which Indian occupancy of tribal lands had been protected on the ground that those cases involved protection of Indians against a state or an individual intruder. In addition, the Court disclaimed any judicial control over the nature or extent of tribal relations. ${ }^{199}$ The only sign of the Court's dissatisfaction with the congressional policy of the era was its reference to the morality theine. ${ }^{200}$ The treaties had created

191. Jones v. Meehan, 175 U.S. 1 (1899).

192. See, e.g., United States v. Nice, 241 U.S. 591 (1916); United States v. Sandoval, 231 U.S. 28, 48 (1913); United States v. Celestine, 215 U.S. 278 (1909). Celestine distinguished, and Nice explicitly overruled Matter of Heff, 197 U.S. 488 (1905)-the only case in this period that espoused the proposition that the congressional policy underlying allotment was designed to end federal jurisdiction over Indians who took allotnents.

193. 187 U.S. 553 (1903).

194. Act of June 6,1900 , ch. 813,31 Stat. 672. The Act was passed to ratify an agreeinent niade by the confederated tribes for the allotment of their land. The tribes maintained that their acceptance of the agreenent had been fraudulently induced by the Indian agents on the reservation. 187 U.S. at 561.

195. Treaty with the Kiowas and Comanches, Oct. 21, 1867, 15 Stat. 581 (1868).

196. The Apaches entered the confederation by a later treaty. Treaty with the Kiowas, Comanches, and Apaches, July 25, 1868, 15 Stat. 589 (1868).

197. Art. XII, 15 Stat. 581, 585.

198. 187 U.S. at 564.

199. Id. at 565 .

200. See text acconpanying note 175 supra. 
a moral obligation ... u upon Congress to act in good faith in performing the stipulations entered into on its behalf. ... . The power exists to abrogate the provisions of an Indian treaty, though presumably [it] will be exercised only when circumstances arise which will not only justify . . . disregarding the stipulations of the treaty, but may deinand [it] in the interest of the country and the Indians theinselves. ... [on the basis of] considerations of governmental policy, particularly if consistent with perfect good faith toward the Indians. ${ }^{201}$

After Lone Wolf, the Court returned to its attempts to mitigate . the effects of the assimilation policy. ${ }^{202}$ As congressional policy began the swing back from assimilation under the Roosevelt administration, the number of important Indian decisions coming out of the Supreme Court on issues of sovereignty tapered off. It was not until the assimilationist philosophy was again in its ascendency in the 1950's that another landmark case came down..$^{203}$

\section{IV}

\section{IN SEARCH OF SELF-GOVERNMENT}

The codification in the 1950's of the assimilatiomist approach, in Public Law 280 and im the termination statutes, ${ }^{204}$ reflected a cliange in national motivations and concerns since assimilation had last held sway at the turn of the century. At the time of the Allotment Act ${ }^{205}$ the primary ulterior inotive was to niake the land available to non-Indians. ${ }^{208}$ The inethod settled on was to dissolve tribal relations and thus end the need for large areas of communal ownership. The federal government was the instrument of change, since the President directed whicli reservations would be subject to allotment and when the trust period for each allotment would end. ${ }^{207}$

201. 187 U.S. at 566.

202. See, e.g., United States v. Nice, 241 U.S. 591, 598 (1916); United States v. Sandoval, 231 U.S. 28, 48 (1913); FeDERAL INDIAN LAW, supra note 2, at 125.

203. One important Eighth Circuit opinion came down in 1956. It followed the Supreme Court's lead in upholding the tribe's power to tax leased land and the tribal court's jurisdiction over an adultery prosecution. Indian tribes, the court found, "still possess their inherent sovereignty excepting only where it has been specifically taken from then, either by treaty or by Congressional Act." The only indication of the prevalent legislative policy of assimilation was in the dictum that while tribal courts were part of the inherent Indian powers which had not been taken away by Congress, "regulatory powers over these judicial establishments have been exercised to promote uniformity, gradual assimilation and other ends." Iron Crow v. Oglala Sioux Tribe of Pine Ridge, 231 F.2d 89, 94, 96 (8th Cir. 1956).

204. See text accompanying notes 119 \& 124 supra. See also H.R. Con. Res. 108, Aug. 1, 1953, 67 Stat. B132, quoted at text accoinpanying note 118 supra.

205. See text accompanying note 97 supra.

206. See text accompanying note 99 supra.

207. Act of Feb. 8, 1887, ch. 119, § 1, 24 Stat. 388. 
In contrast, the legislation of the 1950's focused on dissolving the special relationship between the federal government and the tribes. The increased role permitted the states by Public Law $280^{208}$ was a response to their rising dissatisfaction with the existence of competing sovereignties within their boundaries. ${ }^{209}$ The few Indians who favored the policy of termination were reacting against the paternalism which had traditionally clraracterized their treatment by the Bureau of Indian Affairs. The instruments of change in these prograins were the states, who acted to assume jurisdiction, ${ }^{210}$ and the tribes, who ostensibly agreed to their fate and were given responsibility for planning their future. ${ }^{211}$

The changed concerns reflected in the new termination acts were equally apparent in Indian litigation. Where previously the Supreme Court had served largely as an arbitrator between the federal government and the states or the tribes, ${ }^{212}$ inost confrontations in the last 20 years have been between states and Indians. In 1959 the Supreme Court addressed this new trend, suggesting the rudiments of a test for regulating such state-Indian conflicts.

\section{A. The Infringement Test}

Williams v. Lee $e^{213}$ involved a suit brought in a state court by Lee, a reservation trader, for the balance due from an Indian customer. Williams, a Navajo, attacked the Arizona court's jurisdiction over his person, his sheep, and his debt, all of which were located on the reservation. The Arizona supreme court upheld the trial court's jurisdiction, saying:

Our view is that if the subject matter of the litigation is one that the state court has jurisdiction to try and determine and the federal government has not reserved sole and exclusive jurisdiction over the territory involved, the state officers may enter such territory under the state's sovereign authority and serve the necessary process to enable it to exercise its legitimate jurisdiction. ${ }^{214}$

The opinion completely ignored the existence and possible jurisdictional claim of the tribal courts.

The United States Supreme Court granted certiorari to review this

208. See text accompanying note 120 supra.

209. See note 150 supra.

210. Act of Aug. 15, 1953, ch. 505, 67 Stat. 588. The states enumerated in the statute, to whoin jurisdiction passed immediately, had consented to the transfer of responsibility prior to enactment.

211. E.g., Act of June 17, 1954, ch. 303, 68 Stat. 250, 25 U.S.C. $\S \S 891-902$ (1964) (Menoininee).

212. See Part III supra.

213. 83 Ariz. 241, 319 P.2d 998 (1958), rev'd, 358 U.S. 217 (1959).

214. Id. at $244,319 \mathrm{P} .2 \mathrm{~d}$ at 1000 . 
"[D]oubtful determination . . . of state power over Indians . . .."215 Justice Black, writing for the Court, recognized that the Arizona court had misperceived the interests at stake in the Williams situation. Arizona saw the federal government as the only possible obstacle to assertion of the state's interests. Justice Black pointed out, however, that since Worcester ${ }^{210}$ two governments' interests in Indian affairs had been acknowledged: the tribal governments' interest in matters involving Indians on the reservation ${ }^{217}$ and the federal government's concern for Indian-non-Indian interactions. ${ }^{218}$

Prior to Williams these two interests were protected from state intrusion by the general rule that states could not act in Indian affairs without explicit congressional authorization. ${ }^{219}$ Williams reformulated the rule as "[A]bsent governing Acts of Congress, the question has always been whether the state action infringed on the right of reservation Indians to make their own laws and be ruled by them."220 Implicit in this new "infringeinent test" was the assumption that there were some Indian matters in whicll the states could assert their power without prior Federal permission. Thus the Court no longer recognized total federal preemption of Indian affairs, and to the extent states could now act in areas formerly reserved to the tribes, Indian autonomy was restricted. But there was a contradictory implication in Williams' emphasis on tribal self-government and federal authority over it. ${ }^{221}$ By emphasizing Indian power and prerogatives, Justice Black suggested the existence of Indian interests distinct from the federal interest in Indian regulation ${ }^{22}$-interests which potentially merited defense against subordination to conflicting interests of either the state or federal governments. Unfortunately the boundaries between the competing interests recognized in Williams were left unclarified by the Court's opinion.

While recognizing ultimate congressional authority over Indian affairs, the opimion also depicted a role for the Court in the arbitration of state-Indian disputes. Justice Black characterized the Court as hav-

215. Williams v. Lee, 358 U.S. 217, 218 (1959).

216. See text accompanying note 156 supra.

217. Albeit subject to the plenary power of the federal government.

218. See 358 U.S. at 219-20.

219. Id. The courts had recognized that some litigation was peripherally related to Indian affairs although neither Indian nor federal interests were involved: such cases had, therefore, been left to state court jurisdiction. See, e.g., Utah \& N. Ry. v. Fisher, 116 U.S. 28 (1885) (permitted state taxation of land owned by non-Indian railroad running through a reservation); Pablo v. People, 23 Colo. 134, 16 P. 636 (1896) (state jurisdiction over Indian actions off the reservation upheld).

220. 358 U.S. at 220 .

221. Id. at 223.

222. E.g., maintaining the integrity of the Indian courts and the imviolability of reservation boundaries. See text accompanying note 245 infra. 
ing "consistently guarded the authority of Indian governments over their reservations," 223 although he recognized that the Court had accepted modifications of the Indians' dominion over their territory in certain nonessential respects. ${ }^{224}$ The infringement language was introduced in an attempt to synthesize a generalization about these judicial concessions that would still capture the spirit of the Court's efforts to protect Indian interests.

\section{B. Death of the Old Rule and the Federal-State Relationship}

Before Williams the rule governing state-Indian interactions defined the relationship in terms of federal-state conflicts. ${ }^{225}$ Congress was considered to have preempted the entire field of Indian regulation, and generally, the states could only exercise authority over Indians on reservations where Congress had expressly granted them that power. ${ }^{220}$ Williams, however, suggested that federal preemption was not complete, that there was an area in which the states could act without express congressional authorization as long as they did not infringe on the Indians' right of self-government.

It is unlikely that Justice Black intended his formulation of a test for the state-Indian class of cases to eliminate completely the use of federal preemption. Rather he appeared to be introducing as an additional factor recognition of a class of Indian interests distinct from both state and federal interests. He disapproved the Arizona supreme court's statement that state courts were free to exercise jurisdiction in civil suits by non-Indians against Indians as long as no act of Congress expressly forbade their doing so. ${ }^{227} \mathrm{He}$ analyzed Congress' historical treatment of Indians as resting on "the assumption that the States have no power to regulate the affairs of Indians on a reserva-

223. 358 U.S. at 223.

224. E.g., state court jurisdiction over non-Indians committing crimes against each other on the reservation. Id. at 219.

225. E.g., Donnelly v. United States, 228 U.S. 243 (1913); United States v. Kagama, 118 U.S. 375 (1886); Worcester v. Georgia, 31 U.S. 350, 378, 6 Pet. 515, 559 (1832). Although analytically these may seem the same conflict, there is a difference in practical effect which needs to be taken into account. See text following note 295 infra.

226. See Federal Indian Law, supra note 2, at 122. The Arizona supreme court's version of the pre-Williams rule was that the state could exercise jurisdiction on the reservation except as forbidden by federal law. Although Williams disapproved this statement, Justice Frankfurter resurrected it in Kake v. Egan, 369 U.S. 60, 72 (1962), saying "[A] reservation was in inany cases a part of the surrounding State . . . and subject to its jurisdiction except as forbidden by federal law." (citation ounitted). It should be noted that the cases cited as supporting this rule were cases involving nonIndians. Thus state jurisdiction was allowed in such cases rather than permit nonIndians to hide behind the Indiau's special status. See, e.g., Draper v. United States, 164 U.S. 240 (1896); Utah \& N. Ry. v. Fisher, 116 U.S. 28 (1885).

227. 358 U.S. at 218. 
tion,"228 and on "the understanding that the internal affairs of the Indians remained exclusively within the jurisdiction of whatever tribal government existed." ${ }^{220} \mathrm{He}$ reiterated the preeminence of Congress in the federal-state struggle, asserting that if the authority of Indian governments over their reservations was to be taken away, "it [was] for Congress to do it."230 But having raised the specter of the old rule's demise, the Court left to other courts' judgment the determination of how widely preenption might still apply.

Organized Village of Kake v. Egan, ${ }^{231}$ in which Justice Frankfurter elaborated on Justice Black's test, has been viewed as a clarification of Williams. ${ }^{232}$ More accurately it illustrates how Williams lack of specificity as to the limitations on preemption could, contrary to Justice Black's implicit intent, undermine Indian interests. The village of Kake was engaged in fishing in a manner forbidden by state law. At issue was the right of Alaska to regulate off-reservation fishing in light of the Alaska Statehood Act which provided that the United States should retain "'absolute jurisdiction and control' over . . . 'any lands or other property (imcluding fishing rights), the right . . . to which may be held by any Indians...." "233

Kake used Williams to preclude the possibility of federal preemption in the area of Indian fishing rights in Alaska. As Justice Frankfurter interpreted the Alaska Statehood Act, it was not one of the "governing Acts of Congress" which under Williams would have prevented state action. Rather he interpreted the Court's resort to the infringement test in Williams as support for his argument that "absolute jurisdiction" meant not "exclusive" and therefore "pre-emptive," but "undiminished" jurisdiction. ${ }^{234}$ The result was that Alaska was permitted to regulate the disputed fishing.

Had Kake rested on the determination that state regulation of offreservation fishing would not be a prohibited "infringement of tribal self-government," the decision would have been unassailable in light of Williams. Justice Frankfurter chose instead to deal with the preemption theme from Williams. The result was a severe contraction of the notion of federal preemption. While there was no governing

228. Id. at 220 .

229. Id. at 221-22.

230. Id. at 223.

231. 369 U.S. 60 (1962).

232. See, e.g., Montoya v. Bolack, 70 N.M. 196, 372 P.2d 387 (1962).

233. 369 U.S. at 64.

234. 369 U.S. at 67-68. Justice Frankfurter saw Williams as paralleling Kake because Arizona's clause disclaiming state jurisdiction contained language similar to Alaska's. But Williams did not interpret Arizona's disclaimer clause; it only pointed out the disclaimer would have to be dealt with by the state in any move to assume jurisđiction. 358 U.S. at 222-23 n.10. 
act of Congress (at least under the Court's interpretation) there was, however, a federal interest at stake in Kake. The federal concern was to support the Indians ${ }^{235}$ in defending their concededly vital ${ }^{230}$ interest in fishing against the competing state goals. By ignoring this federal interest Kake restricted the scope of federal preemption virtually to that espoused by Arizona in the Williams case. Kake's formulation seemingly reduced federal involvement to supremacy clause terns. While Williams apparently contracted federal involvement, it gave the states hittle additional power, because it filled the void primarily with Indian sovereignty. Kake, however, provided the states with a great deal of p.ower, ${ }^{237}$ for it left the area opened by the contraction of the federal concern to the states rather than to the Indians.

But Kake was not the last word on the scope of federal preemption. In 1965 the Court vigorously asserted that there are certain areas of applicability for the old rule that without a congressional grant of state authority to act the federal presence preempts the field. In Warren Trading Post v. Tax Commission, ${ }^{238}$ the Court reversed an Arizona supreme court attempt through use of the Williams-Kake test to extend the state's taxation power onto the Navajo reservation. Justice Black's opinion relied solely on the theory that the

apparently all-inclusive regulations [of the Commissioner of Indian Affairs] and the statutes authorizing them would seem in theinselves sufficient to show that Congress has taken the business of Indian trading on reservations so fully in hand that no room remains for state laws imposing additional burdens upon traders. ${ }^{230}$

An argument might have been made under the Williams fornula that since Indians have the power to tax traders on the reservation, ${ }^{240}$ state

235. Brief for United States as Amicus Curiae at 3.

236. 369 U.S. at 61.

237. For subsequent cases which reject Kake's assimilative tendencies, see Seymour v. Superintendent, 368 U.S. 351 (1962) (crimmal jurisdiction). An Indian convicted of burglary in a state court was freed on the grounds that the situs of the crime was within the definition of Indian country where federal courts had exclusive jurisdiction, even though the reservation areas had been subjected to sale, allotment and homesteading. This decision is reminiscent of the Indian liquor law cases where the court allowed the continued operation of the federal prohibition after the situs had been allotted. See text accompanying note 31 supra. Although it did not cite either Williams or Kake, Menominee Tribe v. United States, 391 U.S. 404 (1968), was an even stronger indication of the Court's resistance to the assimilationist doctrine as embodied in congressional programs of the 1950's. There Justice Douglas resorted to strained statutory interpretation to mitigate the effects of Congress' assinilative termination program. The Court held the terminated tribe still has treaty hunting and fishing rights within the old reservation boundaries. See also Warren Trading Post v. Tax Comm'n, 380 U.S. 685 (1965).

238. 380 U.S. 685 (1965).

239. Id. at 690 (footnote omitted).

240. 25 C.F.R. $\$ 252.27$ (c) (1967). 
intrusion into this area would infringe on their exercise of this rulemaking power. Justice Black's resort to the preemption doctrine, ${ }^{241}$ rather than his own infringement test, was, therefore, significant: It suggested that, contrary to the implications of Kake, the Court still found preeinption a valid doctrine for Indian law.

Warren characterized the federal concern as being "that no burden shall be imposed on Indian traders . . . except as authorized by Acts of Congress . . . ."242 The supporting language in the opinion, however, suggested broader preeinptive possibilities by referring to the congressional policy of leaving the Navajo "largely free to run the reservation . . . without state control" and leaving "the State with no duties or responsibilities respecting the reservation Indians."243 Warren's treatment of Kake strengthened this suggestion. Kake was mentioned in a footnote along with Williams as authority for the proposition that "state laws have been permitted to apply to activities on Indian reservations, where . . . specifically authorized by acts of Congress, or where they clearly do not interfere with federal policies concerning the reservations."244 This is an obvious retreat from the permissive statement in Kake itself that state laws may apply to Indians in the absence of an express congressional act. ${ }^{245}$ While Warren's partial restoration of the old preemption doctrine did place a restraint on the states, it is unfortunate that the result was achieved by preeinption rather than by recognition of the Indians' interests. This threat to the concept of independent Indian interests latent in Warren, has not, however, been implemented in subsequent cases since Warren has been cited chiefly in traditional preeinption circumstances. ${ }^{246}$

Two threads run through the Williams-Kake-Warren trilogy. The first is the question of federal preemption. Prior to Williams the black letter rule was that the states could only exercise power over Indians pursuant to an express congressional grant. Williams, although still emphasizing federal authority, indicated that federal preemption

241. First applied to an Indian case in Worcester v. Georgia, 31 U.S. 350, 376, 6 Pet. 515, 561 (1832).

242. 380 U.S. at 691.

243. Id. at 690,691 . See text accompanying note 251 infra for later extension of the doctrine.

244. Id. at 687 n.3 (emphasis added).

245. 369 U.S. at 75. The retreat was accomplished, it should be noted, by reinterpreting Kake which had not limited the states by reference to activities or federal policies.

246. Compare Pierce v. State Tax Comm'n, 52 Misc. 2d 10, 274 N.Y. Supp. 2d 959 (1966), aff'd, 29 App. Div. 2d 124, 286 N.Y. Supp. 2d 162 (1968), with Makah Indian Tribe v. Tax Comm'n, 72 Wash. 2d 613, 434 P.2d 580 (1967). But see Makah Indian Tribe v. Clallam County, 73 Wash. 2d 774, 440 P.2d 442 (1968), where text quoted at note 242 supra is used to support the rejection of county efforts to assess on-reservation personal property for a county tax. 
was by no means so pervasive. Williams suggested that there were areas where the states could act without explicit authorization so long as they did not infringe on the Indians' right of self-government. Kake went far beyond Williams and appeared to abandon the notion of federal preemption in favor of a supremacy clause test: the states could act anywhere the federal government had not denied them the right. Warren restored in part the preemption doctrine and established administrable, although not immutable, boundaries to the scope of federal preemption in Indian litigation-the areas covered by acts of Congress and by federal policies concerning reservations.

The second theme is the scope of Indian sovereignty. Williams for the first time recognized an independent Indian interest in selfgovernment which stood as a barrier to state involvement in Indian affairs. This was a development of major significance for it carried with it the suggestion that these independent Indian imterests might also provide a check on the power of the federal government. However, this idea has not been vigorously pursued in subsequent cases.

Kake essentially ignored this idea, since it dealt only with the preemption issue, and possibly because the Indian interests threatened did not involve "self-government." Warren presented a clear opportunity for the Court to reassert the preeminence of independent Indian interests, but the Court sidestepped the issue by resorting to preemption principles. While this approacli was unfortunate, it did not necessarily deal a death blow to the concept of independent Indian interests. But it did leave the extent and exclusive power of tribal government undefined by the nation's highest court.

\section{The State-Indian Relationship and the Application of Williams}

Attempts to inuplement the Williams test in regulating state-Indian relationships have been complicated by Justice Black's failure to identify precisely what factors his judgment turned on. What will "undermine the authority of the tribal courts" and "infringe on the right of the Indians to govern theinselves" will necessarily vary with the facts, and Williams left lower courts with little to guide their decisions. In Williams the infringement could have been the circumvention of the tribal court's exercise of its carefully nurtured civil and criminal jurisdiction which presumably encompassed the subject matter and both the parties, ${ }^{247}$ it could also have been the state's on-reservation service of process and levy of its writ of attachment against the Navajo's sheep. ${ }^{248}$

247. 358 U.S. at 222.

248. See the language of the Arizona supreme court quoted at note 212 supra. See also Kane, Jurisdiction over Indians and Indian Reservations, 6 ARIz. L. REv. 237, 249 (1965). 
Although Williams has been widely cited by state supreme courts, the uses to which they have put it subvert Williams' significance, smce that depends on the extent to which it offers additional protection for tribal governments against state usurpation of their power. Most of the cases simply use the Williams formulation to reach a result that would have been possible, if not imevitable, previously because they involve only non-Indians or off-reservation events. ${ }^{249}$

A recent Ninth Circuit decision, however, refined the Williams test and suggested a more precise and effective method of applying it. In State ex rel. Merrill $v$. Turtle ${ }^{250}$ the court of appeals held that Arizona could not go on the Navajo reservation to extradite an Indian fugitive to Oklahoma after the tribe had refused extradition. The Navajo had a statute which permitted extradition to adjacent states, but Oklahoma was not included. The court not only characterized the power to extradite as a significant trait of sovereignty, ${ }^{251}$ but it found that the tribe was properly exercising its power under its ordinance. The state's effort to extradite in circumstances deliberately omitted from the tribal legislation created the clearest possible case of "infring[ing] on the right of the reservation Indians to make their own laws and be ruled by them.".252 The fact that the tribe had legislated on extradition left no rooin for the state to act in the area. ${ }^{253}$ In effect, the tribe's legislative activity had preempted the state. Turtle is the first decision expressly to utilize the preemption primciple from federalstate interactions in an Indian-state confrontation. ${ }^{254}$ This application of Williams provides a much more workable gauge of infringement than any previous cases have. It does not involve a philosophical search for the basic elements of self-government, but rather a practical, concrete inquiry into whether the tribe has acted governmentally in the

249. E.g., Sigana v. Bailey, 282 Minn. 367, 164 N.W.2d 886 (1969) (state has no jurisdiction over vehicular tort between Indians on reservation). For the same result before Williams, see, e.g., State v. Begay, 63 N.M. 409, 320 P.2d 1017 (1958); State v. Warner, 71 N.M. 418, 379 P.2d 66 (1963) (state jurisdiction when no Indians involved in on-reservation accident); Batchelor v. Charley, 74 N.M. 717, 398 P.2d 49 (1965) (state jurisdiction over off-reservation Indian's debt); In re Holy-Elk Face, 104 N.W.2d 308 (N.D. 1960) (state juvenile custody over off-reservation Indian children); State ex rel. Adams v. Superior Ct., 57 Wash. 2d 181, 356 P.2d 985 (1960) (no state jurisdiction over on-reservation children); Whyte v. District Ct., $140 \mathrm{Col}$. 334, 346 P.2d 1012 (1959) (no state jurisdiction over on-reservation divorce proceedings).

250. 413 F.2d 683 (1969).

251. Id. at 686 .

252. Id. at 686, citing Williams v. Lee, 358 U.S. 217, 220 (1959).

253. The court noted that the tribal ordinance had the approval of the Secretary of the Interior. 'This only indicates continued federal acknowledgement of the tribes' power to extradite (which was first recognized in treaties; see 413 F.2d at 686) which made the ordinance a proper exercise in self-government.

254. Compare the implication of the Warren language quoted in text accompanying note 241 supra. 
given area. Problems, such as what law will govern in the absence of tribal legislation and whether the tribe's active exercise of its powers is a necessary element of the preclusion, remain; but these questions can be resolved by reference to established principles from the body of preemption law that has grown up around the commerce clause. The court of appeals' use of Williams to support the principle of tribal preemption of a state's exercise of authority has finally provided effeetive guidance as to how Williams should be applied.

\section{A Willians Analogy in Federal-Indian Relations}

Williams has also been used by federal courts in determining whether they or the tribal courts have jurisdiction in a given case. Since Williams involved a state-Indian relationship, the rule is not automatically apphicable in all situations involving federal-Indian interactions. But the federal courts have not always recognized this. As a result Williams has been imappropriately applied, as for example, in a case involving not tribal, but individual constitutional rights.

Only ten months after the Williams decision the Court of Appeals for the Tenth Circuit affinned dismissal of a religious group's challenge of the constitutionality of a Navajo ordinance prohibiting the importation of a drug central to their religious practices. The court cited Williams as the most recent confirmation of the old theme that "[F]ederal courts are without jurisdiction over matters involving purely penal ordinances passed by the Navajo legislative body for the regulation of life on the reservation."255 Application of the Williams formula in these circumstances meant that a test originally devised to protect tribal sovereignty against state encroachment was instead used to deprive individual Indians of any protection against the tribal government. ${ }^{250}$

The use of Williams in the federal-Indian context is appropriate, however, where federal imterests are not involved. A case exemplifying this situation is Littell $v$. Nakai, ${ }^{267}$ a Ninth Circuit diversity case involving an action to prevent tortious interference wth the Navajo General Counsel's contract by the tribal chairman. Littell was analagous to the usual state-Indian conflict because, as with any diversity case, the federal court had to act as a state court would have in an Indian contract action. ${ }^{258}$ This was unlike the religious freedom situation where the subject matter of the suit raised constitutional questions that should have been of particular federal concern. As the court of

255. Native American Church v. Navajo Tribal Council, 272 F.2d 131, 134 (10th Cir. 1959).

256. See text accompanying note 229 supra.

257. 344 F.2d 486 (9th Cir. 1965).

258. Id. at 488 . 
appeals said in affirming the district court's dismissal of the action for want of jurisdiction, "[F]ederal court jurisdiction would be equally disruptive of the ... [strong congressional policy to vest the Navajo tribal government with responsibility for their own affairs] . . . as would state court jurisdiction." ${ }^{259}$ The federal courts' difficulty is largely the result of indiscriminately applying Williams out of the context of state-Indian relations. Where there is no governing federal legislation or policy the case may be analagous to a state-Indian conflict and Williams may then be appropriate. Where the federal government asserts any real interest, however, the Williams language does not apply and tribal self-government cannot preclude the effectuation of federal policies.

\section{E. The Indian and His Tribe: Constitutionalization}

The Supreme Court has not provided any recent guidance in how non-Indian courts are to deal with the relationship in which Indian self-government is most deeply enmeshed, that between an Indian and his tribe. Neither Williams nor the subsequent decisions of the Court offer principles readily applicable to this sensitive area. These inadequacies may in part be attributable to the Court's awareness that Congress is in the midst of a period of transition.

During the period between the federal government's retreat from termination in the late 1950 's ${ }^{260}$ and the passage of the Civil Rights Act in $1968^{261}$ there was no legislative hint of what the new congressional posture might be. Now Congress is finally evolving a new policy, not directly descended from either the separationist or the assimilatiomist line. The Indian Civil Rights Act characterizes this new policy. It represents a congressional effort to strengthen tribal institutions while drawing them nearer to non-Indian standards. ${ }^{202}$ Forcing the tribes to approximate national standards of governmental behavior, however, requires the sort of interference with Indians' internal affairs that was forbidden to the states by Williams ${ }^{263}$ and disavowed by the federal governinent since the early treaties. ${ }^{264}$ The Supreme Court might distinguish this interference because of the constitutional issues involved, ${ }^{265}$ as it does in many other circumstances; but since the Court lias yet

259. Id. at 489.

260. See Part II(E) supra.

261. See text accompanying note 128 supra.

262. Act of April 11, 1968, Pub. L. No. 90-284, $\$$ 201-03, 82 Stat. 77, 25

U.S.C. $\$ \$ 1301-03$ (Supp. V, 1969). See text accompanying note 141 supra.

263. See text accompanying note 218 supra.

264. See text accompanying note 73 supra.

265. E.g., right to counsel, free exercise of religion. See text accompanying note 131 supra. 
to react to this shift in policy, there is now a gap between the evolution of Indian law principles and the needs of present cases. State court decisions which have either leapt into the void or, with the federal courts, ignored Williams in searching for some new statement of appropriate principles, make this readily apparent.

Even before the Indian Civil Riglits Act became law in 1968, and in spite of Williams, a few lower courts had begun questioning the unrestrained exercise of tribal self-government when it threatened individual riglits. ${ }^{206}$ A 1965 Nintl1 Circuit decision held that the federal district court in Montana had jurisdiction to determine the constitutional validity of an Indian's detention by the tribal court. ${ }^{267}$ The court questioned the continuing validity of the assertion that the Constitution applies to Indians in the conduct of tribal affairs "only when it expressly binds them, or is made binding by treaty or act of Congress," but found it unnecessary to reach the constitutional issue. ${ }^{268}$ It based its decision on the limited ground that the federal district court had jurisdiction to review proceedings in Courts of Indian Offences because they could be characterized as "arms of the federal government" 269 from which liabeas corpus would he. The court thus indicated the caution with which it ventured into this uncharted domaim.

In only one instance before the Civil Riglits Act of 1968 was an Indian guaranteed a forum for his challenge of a governmental action of his tribe. The Supreme Court of Idaho recognized the otherwise unprotected position of the Indian plaintiff in a suit brouglit in a state court for mandamus to compel restoration of the plaintiff to his position as an elected member of the tribe's business council. ${ }^{270}$ The court recognized Congress' plenary power over the Indians and its preemption of state law within Indian territory in matters concerning Indians except as specifically granted to the states by federal law. ${ }^{271}$ It also acknowledged that the tribes liave the power, "absent some treaty provision or act of Congress to the contrary," own government and to enforce their laws in their own courts. The

266. Compare the cases following with Native American Church v. Navajo Tribal Council, 272 F.2d 131 (10th Cir. 1959), discussed at note 259 supra, and with United States v. Blackfeet Tribal Court, 244 F. Supp. 474 (D. Mont. 1965), where the judge stopped with an admonition to the tribal court to heed due process. Id. at 478.

267. Colliflower v. Garland, 342 F.2d 369 (9th Cir. 1965). Three years later the Indian Civil Rights Act specifically granted Indians this right to federal court habeas corpus review.

268. Id. at 377.

269. Created under the Secretary of the Interior's authority pursuant to 25 C.F.R. \$ 11.1-.37 (1969).

270. Boyer v. Shoshone-Bannock Indian Tribes, 92 Idaho 257, 441 P.2d 167 (1968).

271. Id. at $260,441 \mathrm{P} .2 \mathrm{~d}$ at 170 .

272. Id. 
court found, however, that Public Law 280 provided congressional authority for the state's interference in this tribal matter. Pursuant to Public Law 280, Idaho had by statute provided for assumption of concurrent jurisdiction in civil matters with the consent of the respective tribal governments. ${ }^{273}$ The case was renanded to determine whether the tribe had consented to state jurisdiction. The surprising element of the supreme court's order was its insistence that the petitioner have an opportunity to confront the tribe in some court; if the district court found the action should be referred to the tribal court ${ }^{274}$ and the tribal court refused "to entertain jurisdiction of the cause, then the [state] district court [was] directed to assume jurisdiction thereof and inake a deternination of the justiciable controversy."275 The state court was apparently being authorized, even without the consent statutorily required in Idaho, to interfere in an area which was clearly self-government. The intrusion could only be justified by attributing great weight to the individual rights involved. ${ }^{276}$

The passage of the Indian Civil Rights Act indicated that Congress shared the lower courts' concern for the protection of the individual against the tribe. Since 1968, the federal courts have used the act to confirm their jurisdiction in Indian-tribe confrontations. In Dodge v. Nakai ${ }^{277}$ the Arizona federal district court enjoined the tribal council from expelling the director of the Navajo Legal Services prograin froin the reservation. ${ }^{278}$ The court assumed jurisdiction because rights guaranteed by Title II of the Civil Rights Act were at stake. ${ }^{279}$ It did so in spite of the fact that plaintiffs had not exhausted their remedies by first seeking relief from the tribal court. ${ }^{280}$ In the process the court imported new policy choices into Indian law. In the Dodge jurisdiction opimion the court found the long-recognized considerations of strengthening tribal institutions and avoiding participation in local reservaton conflicts to be outweighed by factors of convenience

273. Id. at 261, 441 P.2d at 271. This opinion came down after the Indian Civil Rights Act of 1968 was passed with the sections repealing Public Law 280 but the Idaho response to Public Law 280 was, as provided in the 1968 Act, unaffected by the changes.

274. Presumably the tribe had not consented to state jurisdiction since otherwise the state would have concurrent jurisdiction.

275. 92 Idaho at 262,441 P.2d at 172 .

276. The issue of reinstatement was moot by the end of the appeal since the term of office at stake had expired. That left only a damage claim to be balanced against the well-established policy of tribal authority over internal affairs.

277. 298 F. Supp. 17 (D. Ariz. 1968). The court's opinion on the inotion to dismiss for lack of jurisdiction is a good example of the complexity involved in Indian cases.

278. Dodge v. Nakai, 298 F. Supp. 26 (D. Ariz. 1969) (opinion on the merits).

279. The right to due process of law and freedom of expression. Id. at 32.

280. 298 F. Supp. 17, 25. The question of exhaustion of remedies was not settled by the Act. 
and efficiency in getting all the parties and issues together in one court in one proceeding. Not only were these new considerations introduced, but they prevailed in spite of being in direct conflict with the notion of the importance of tribal sovereignty. The efficiency factors were perhaps a corollary not anticipated by Congress, but the thrust of the Indian Civil Rights Act was to incorporate into Indian litigation and government some of the limitations of the American political inainstream where efficiency is a significant value.

In the opinion on the merits in Dodge, the Ninth Circuit applied the substantive provisions of the 1968 Civil Rights Act. The court acknowledged that the power to exclude non-Navajos froin the reservation "was clearly an exercise of the 'powers of self-government' possessed by the Navajo Tribe."281 But in holding that exclusion for expression of an opinion was an abridgement of free speech, ${ }^{282}$ the opinion also pointed out that the tribe was now held to new standards with respect to the manner in which it could exercise its autonomy and the objectives which it could legitimately pursue. ${ }^{283}$

Althougl these decisions have recognized the need of individual Indians for judicial protection of their rights, in addition to the tribes' need for protection agamst external pressures, the courts' limited, deliberate steps reflect an awareness that the United States Supreme Court has yet to respond to the latest congressional policy. It is necessary that the Court indicate whether it will pursue its traditional line of separationist decisions or direct itself to the reconciliation of its old posture to the new policy. The conclusion outlines low the traditional principles should be applied to accomplish the second alternative.

\section{CONCLUSION: THE SHAPE OF THE FUTURE}

It is not up to the courts, at any level, to decide what the role of the Indian in this country is to be. The judicial process is not suited to the accumulation of appropriate information, nor to the evaluation of interests, priorities, and the impact of alternatives which must precede such a far ranging piece of social legislation. This basic decision has been left by the political scheme of the nation to Congress.

Although the basic decision is not for the courts, they can haveas they have had on the question of federalism-a significant impact on the progress toward the goal defined, whether the definition is to be found in the Constitution or in the acts of Congress. Even if Congress is assumed to have plenary power over states and tribes in Indian

281. 298 F. Supp. 26, 29.

282. The exclusion action was also found to be legislative, and thus an impermissible bill of attainder.

283. See also Spotted Eagle v. Blackfeet Tribe, 301 F. Supp. 85 (D. Mont. 1969). 
affairs, the courts still have a vital role to play in the exercise of that power. Congress' control of various aspects of Indian life is limited ultimately only by its own self-restraint. However, the Court can encourage that self-restraint by defining limits of appropriate congressional activity. It can also mitigate the effects of congressional overreaching by narrow construction of statutes. ${ }^{284}$ In the areas of stateIndian and tribe-Indian interactions, where Congress does not often exert its power, the Court has its most significant influence. Thus, the Court and Congress exercise complementary powers in Indian questions with the Court's authority varying as Congress chooses whether or not to act.

At the core of the difficulties facing both Congress and the Court in dealing with the Indians is the definitional problem. Congress has never taken up its responsibility of clearly defining the national goal regarding the status of the Indian. The closest it has come to disclosure of a goal is the vague intimation, from its explanations of its policies and programs, that the national search for a more equitable and just society imcorporates the Indian. ${ }^{285}$ Since the early days of the Union when the legislative measures were isolated responses to particular confrontations between non-Indian desires and Indian expectations without the benefit of any underlying policy ${ }^{286}$ Congress lias tried many different prograins in pursuit of the two distinct policies of separation and assimilation. ${ }^{287}$

The political nature of Congress effectively guarantees continuing fluctuations in pohcy and programs of the sort which have plagued Indians since the 1820's. Having the ground rules of one's life constantly subject to change at soneone else's discretion necessarily creates an atmosphere of uncertainty in which it is difficult, if not impossible, for creative leadership to emerge and to guide social and cultural evolution. The effect on the Indians of more than a century of such an existence has been widespread social, cultural, and economic disintegration. ${ }^{288}$ A more reliable source of stability and security than Congress is necessary to future Indian growth.

284. See, e.g., United States v. Celestine, 215 U.S. 278, 290 (1909), where the Court refers to the rule "that the legislation of Congress is to be construed in the interest of the Indian . . . ." This rule no doubt derived from the similar treatinent given treaties ever since Worcester v. Georgia, 31 U.S. 350, 374, 6 Pet. 515, 552 (1832).

285. There are few descriptive words of the genre of "integration," "assimilation," "nuainstream" which do not have negative connotations anong Indians who have long since learned that pretty phrases are the non-Indians' facade for a multitude of conteniplated sins, generally assimilative in nature.

286. See text accompanying note 74 supra.

287. See Parts $\Pi(B)$, (C) supra.

288. See, e.g., A. Josephy, JR., The IndiaN HerItage of AMERICA, ch. 27 (1968). 
The Supreme Court, in contrast to Congress, has followed a fairly consistent policy in its treatment of Indian cases. In walking the fine line between succumbing to the political vagaries of Congress and open contravention of its explicit policies, the Court's decisions have contimuously favored separationist or anti-assimilationist results. This consistency is attributable largely to the Court's application of three principles derived from the earliest cases: First, that the tribes have inherent sovereignty; ${ }^{289}$ second, that Congress ultimately controls all Indian relations, thus limiting both state and Indian powers; ${ }^{200}$ and third, that because of the way Americans, both as a nation and as individuals, have dealt with the Indians, fairness requires that Indian interests be carefully gnarded in the courts. ${ }^{201}$ Thus the Court has confronted the problems raised by congressional vacillations, and has tried to develop a principled method of regulating the movement toward a goal only hinted at by Congress. Since the judicial process is by nature evolutionary, building on what has gone before, a measure of stability and predictability is available from the Court as it is not from Congress. The bitter experience of Indians under past abrupt congressional responses $^{292}$ to their condition indicates that non-Indian-Indian relations need to be given time to evolve rather than being expected to reach the heights of social accord immediately. This evolutionary process cannot occur, as the experience of the past 200 years has demonstrated, with the Indians isolated from the non-Indian world; it requires interaction between the two. Since the demise of termination, Congress has been reluctant to attempt another comprehensive solution to Indian problems which might provide the framework for that interaction. In the absence of a definitive congressional solution the Supreme Court will have to fill the gap. The Court's experience as an arbitrator and conservator of Indian interests, as well as the consistency offered by its institutional characteristics, leave it well suited to deal with an elusive congressional policy and to supervise the requisite interaction. ${ }^{293}$

The cases of the last decade reveal the struggle to redefine the outlines of Indian law in light of the new types of conflicts coming to the courts. ${ }^{204}$ To cut away the confusion, the Supreme Court must

289. Worcester v. Georgia, 31 U.S. at 389, 6 Pet. at 561.

290. Id. at 380,6 Pet. at 561 .

291. United States v. Kagama, 118 U.S. at 384.

292. E.g., allotment, at note 97 supra; termination, at note 124 supra.

293. The Court's historical insistence on separationist policy results need not conflict with successful adininistration of interaction if the Court recognizes that separation was a device intended to protect Indians when their rights were not clearly recognized and neither their political institutions nor those of the surrounding settlers were operating at a level of strength and sophistication that would guarantee those rights. To the extent the institutions have since evolved to such levels, the theory of isolation is as obsolete as its physical reality.

294. See text accompanying note 210 supra. See also Part IV(C) supra. 
confront the basic definitional problem which underlies Indian law and provide a clear, principled framework within which to consider Indian cases. The tribes' unique position as a congressionally acknowledged, and judicially and historically confirmed, third unit of government ${ }^{205}$ within the nation but not included in the federal system necessitates a conceptual structure in which the relationships arise out of a recognition of the stakes of the various parties involved. From this foundation the Court should be able to derive the principles necessary to its futurc, reasoned supervision of non-Indian-Indian interaction. The relationships are created by what might be called an interest triangle consisting of the federal and state governments and the Indian, whether as a tribe or as an individual. Four basic patterns emerge: Federal-Indian conflicts of interest; state-Indian conflicts; federal state conflicts; and imdividual Indian-tribal government conflicts. Once the framework is accepted, determination of a given case's place within it will be the threshold question in each controversy.

The federal-Indian relationship was the first to develop. It was crystallized in the original treaties. At first federal concern centered on the consolidation of federal power in the face of the Indians' potential threat. The Indians can hardly be said to constitute a threat to national power any more, but this interest has been replaced by concern for the smooth running of the federal system. The Indians' stake in this relationship is the preservation of as inuch of their original sovereignty as possible, since only with some residuun of resources and independent powers will they be able to participate actively and meaningfully shaping their own roles in national life. The Indians' interest lias remained unaltered over the years, although its manifestation has changed in response to the nature of the threat facing them. ${ }^{296}$ The fact that federal supremacy lias so often overridden Indian interests, chipping away at their powers, has imcreased the urgency and weiglt which should be given to this interest. The principle of fairness slould enter imto decisions involving this relationship to offset the size and power advantage of the "conqueror." The Indian interests should be given greater weight than they have been in the past, and the federal government, in order to prevail against those interests, should be held to sucl a high standard of national benefit that the issue in question would have hittle to do with Indian relations per se.

295. The tribes have never been officially incorporated into the federal system but their effective integration is the implied and necessary tendency of using the nation's courts to administer tribal interactions with the rest of the system.

296. See, e.g., Menominee Tribe of Indians v. United States, 391 U.S. 404 (1968) (termination); Lone Wolf v. Hitchcock, 187 U.S. 553 (1903) (allotment); The Cherokee Tobacco, 78 U.S. (11 Wall.) 616 (1870) (treaty tax-free provision abrogated). 
In this way the Court would also be avoiding complicity in the immoral taint which it lias seen as characterizing most governmental dealings with Indians. ${ }^{297}$

The nature of the conflicts of interest between states and Indian tribes has not changed much in their long history. The Indian stake is much the same as it is against the federal government, but the two sovereignties liere are mucli more equal, both conceptually and in terms of their constitutional powers. The conflict is necessarily stronger at this level because of the physical proximity of the competitors for space and resources and the similarity, and hence overlap, of their governmental functions. The principle regulating interaction between the states and the Indians sliould be a laissez-faire notion, allowing eacli as much freedoin to act as possible. The separationist policy was a device, perlıaps dictated by fairness considerations, used to protect the vulnerable Indian freedom to act in an age when its destruction was otherwise certain. The need for sucl an extreme policy should diminish as tribal institutions grow stronger.

There will continue to be a need for externally imposed restraints on state action, as there is in interstate relationships. If the preWilliams rule that states could not interfere on Indian reservations without express congressional authorization were revitalized, Congress would need to be more actively involved than it has been in opening up areas for state-Indian interaction, and more generous in allowing power to the Indian. Congress lias not yet shown such inclinations. As long as Congress does not assume a more active role, and thus leaves the administration of this relationship solely to the courts, ${ }^{208}$ the Turtle principle that states are precluded from acting in certain areas by the existence of tribal legislation and activity should govern state-Indian interactions.

The federal-state conflict is an outgrowth of the state-Indian conflict. Altliougl the two appear to be mucli the same, and presumably both could be controlled under the assumed plenary power of Congress, there are two distinguishable classes of interests involved, and they need to be treated separately. The Court's failure to make explicit this distinction las aided state erosion of Indian interests. ${ }^{209}$ In cases like Worcester and Warren Trading Post the supremacy clause and the federal preemption doctrine operate indirectly to preserve Indian freedoin to act by excluding the states. ${ }^{300}$ These doctrines vindicate fed-

297. See text accompanying note 175 supra.

298. It is assumed that Congress has neither the will nor the resources to closely regulate Indians itself.

299. See text following note 230 supra.

300. Whether courts can restrain the Bureau of Indian Affairs from expanding to fill the vacuum administratively remains to be seen. 
eral interests which control in non-Indian contexts as well. ${ }^{301}$ Such cases represent rebuffs to the states' challenges of federal authority. The federal interest present in Indian-state conflicts is not so universal; it is the concern for the preservation of Indian autonomy. History has repeatedly shown that this is a comparatively weak and vulnerable federal concern, one often outweighed in legislators' minds. But for the Indians, it is precisely those areas, unique to them, and thus not of universal concern, ${ }^{302}$ that are most important to protect by giving them the added weight of independent acknowledgment.

This is not to say that the federal preclusion of state action does not work to the Indians' benefit. But federal preemption is only necessary in circumstances where the Indians' inherent sovereign powers do not operate themselves because the federal government, by treaty or other enactment, previously preempted Indian action in the area. In such a situation fairness dictates that federal imterests, because they are cloaking the Indians', should prevail. It would put the Indians in a stronger position for future struggles, however, if the power were returned to them to exercise directly. Since Congress can delegate its responsibilities and jurisdiction to the states, there would seem to be no logical impediment to similar delegations to the tribes. ${ }^{303}$ But until Congress does so, the courts inust use whatever devices are available to reach equitable results.

The relationship between the individual Indian and his tribe was the area historically free from outside intermeddling. As a consequence, the Civil Rights Act of 1968 opened wide a field ${ }^{304}$ which has liad very little judicial attention compared to the other three relationships. It may well prove to be the most crucial and difficult class of relationships for which to derive appropriate principles. Outside interference in tribal self-government for protection of individual freedoms is as neeessary as are similar restraints on state or federal governments. National adherence to the primciple of imdividual freedom creates a federal interest of mucl greater weight than any claim of local sovereignty can muster. The same principle of individual freedom was basic to many Indian societies also, ${ }^{305}$ but in imposing non-Indian governmental institutions on tribes out of context, the safeguards for individuals in the American system were not carried over to replace the

301. E.g., regulation of commerce, protection of an individual's constitutional rights.

302. E.g., the functioning of tribal councils and tribal courts.

303. There would, however, undoubtedly be a considerable political obstacle in the form of state opposition to the strengthening of the tribes.

304. See Comment, The Indian Bill of Rights and the Constitutional Status of Tribal Governments, 82 HARV. L. REv. 1343 (1969), for one view of the ramifications of the Indian Civil Rights Act.

305. A. JosepHY, JR., supra note 286 , at 34. 
built-in safeguards of Indian society which were lost with the displaced institutions.

The danger in the implementation of the Indian Civil Rights Act is that the standards which have been developed for state and federal conformity to the Bill of Rights will be transplanted to the Indian field in their entirety. Instead of following this pattern of governmental action, which created the void in the first place, the courts should deliberately set out to acquaint themselves with the standards considered appropriate among the tribes whose members' rights are involved. After such an evaluation, the court will be in a better position to decide to what extent the national standards are appropriate, to what extent they are necessary, and, if there is a conflict between Indian and nonIndian standards, which are more suited to the achievement of the ultimate goal of full, active participation through the intermediate enhancement of both individual freedom and institutional strength. While courts have not often made such inquiries in Indian cases, the Civil Rights Act now particularly invites consideration of such factors by making concessions to Indian governments instead of applying the Bill of Rights in toto. ${ }^{308}$

The cases which will be coming before the Court in the next few years, both those arising out of the Civil Rights Act and those, like Turtle, which involve other relationships, will offer opportunities for the courts to redefine classes of Indian cases in terms of relationships and to state unequivocally the determinative primciples to be used. They must take advantage of these opportunities to continue the evolutionary process which has characterized Indian law and to provide the requisite basis of consistency in a period of tremendous change for Indians.

Robert Ericson

D. Rebecca Snow

306. See note 130 supra. See Hearings on H.R. 15419, supra note 130, at 134. 